\title{
Presynaptic Calcium Channels
}

\author{
Sumiko Mochida
}

Department of Physiology, Tokyo Medical University, Tokyo 160-8402, Japan; mochida@tokyo-med.ac.jp; Tel.: +81-333516141

Received: 27 March 2019; Accepted: 26 April 2019; Published: 6 May 2019

\begin{abstract}
Presynaptic $\mathrm{Ca}^{2+}$ entry occurs through voltage-gated $\mathrm{Ca}^{2+}\left(\mathrm{Ca}_{\mathrm{V}}\right)$ channels which are activated by membrane depolarization. Depolarization accompanies neuronal firing and elevation of $\mathrm{Ca}^{2+}$ triggers neurotransmitter release from synaptic vesicles. For synchronization of efficient neurotransmitter release, synaptic vesicles are targeted by presynaptic $\mathrm{Ca}^{2+}$ channels forming a large signaling complex in the active zone. The presynaptic $\mathrm{Ca}_{\mathrm{V}} 2$ channel gene family (comprising $\mathrm{Ca}_{\mathrm{V}} 2.1$, $\mathrm{Ca}_{\mathrm{V}} 2.2$, and $\mathrm{Ca}_{\mathrm{V}} 2.3$ isoforms) encode the pore-forming $\alpha 1$ subunit. The cytoplasmic regions are responsible for channel modulation by interacting with regulatory proteins. This article overviews modulation of the activity of $\mathrm{Ca}_{\mathrm{V}} 2.1$ and $\mathrm{Ca}_{\mathrm{V}} 2.2$ channels in the control of synaptic strength and presynaptic plasticity.
\end{abstract}

Keywords: $\mathrm{Ca}^{2+}$ channels; synaptic transmission; G-proteins; synaptic proteins; $\mathrm{Ca}^{2+}$ binding proteins

\section{Introduction}

Presynaptic $\mathrm{Ca}^{2+}$ entry into the active zone (AZ) occurs through voltage-gated $\mathrm{Ca}^{2+}\left(\mathrm{CaV}_{\mathrm{V}}\right)$ channels which are activated membrane depolarization and triggers synchronous neurotransmitter release from synaptic vesicles (SVs). Multiple mechanisms regulate the function of presynaptic $\mathrm{Ca}^{2+}$ channels [1-4]. The channel activity for opening, closing, or inactivation in response to membrane depolarization changes every few milliseconds during and after neuronal firing, resulting in control of synaptic strength [3,4]. Following a brief overview of $\mathrm{Ca}^{2+}$ channel structure/function, this article reviews the molecular and cellular mechanisms that modulate the activity of presynaptic $\mathrm{Ca}^{2+}$ channels in the regulation of neurotransmitter release and in the induction of short-term synaptic plasticity. To understand the physiological role of $\mathrm{Ca}^{2+}$ channel modulation in the regulation of synaptic transmission, a model synapse formed between sympathetic, superior cervical ganglion (SCG) neurons in culture was employed for functional study of channel interaction with G proteins, SNARE proteins, and $\mathrm{Ca}^{2+}$-binding proteins which sense residual $\mathrm{Ca}^{2+}$ in the $\mathrm{AZ}$ after the arrival of an action potential $(\mathrm{AP})$.

\section{Presynaptic $\mathrm{Ca}^{2+}$ Channels}

$\mathrm{Ca}^{2+}$ currents have diverse physiological roles and different pharmacological properties. Early investigations revealed distinct classes of $\mathrm{Ca}^{2+}$ currents which were identified with an alphabetical nomenclature [5]. P/Q-type, $\mathrm{N}$-type, and R-type $\mathrm{Ca}^{2+}$ currents are observed primarily in neurons, require strong depolarization for activation [6], and are blocked by specific polypeptide toxins from snail and spider venoms [7]. P/Q-type and $\mathrm{N}$-type $\mathrm{Ca}^{2+}$ currents initiate neurotransmitter release at most fast synapses $[1,8,9]$. The $\mathrm{Ca}^{2+}$ channels are composed of four or five distinct subunits (Figure 1a) $[8,10]$. The $\alpha 1$ subunit incorporates the conduction pore, the voltage sensors and gating apparatus, and target sites of toxins and intracellular regulators. The $\alpha 1$ subunit is composed of about 2000 amino acid residues and is organized in four homologous domains (I-IV) (Figure 1b). Each domain consists of six transmembrane $\alpha$ helices (S1 through S6) and a membrane-associated P 
loop between S5 and S6. The S1 through S4 segments serve as the voltage sensor module, whereas transmembrane segments S5 and S6 in each domain and the P loop between them form the pore module [11]. The intracellular segments serve as a signaling platform for $\mathrm{Ca}^{2+}$-dependent regulation of neurotransmission, as discussed below.

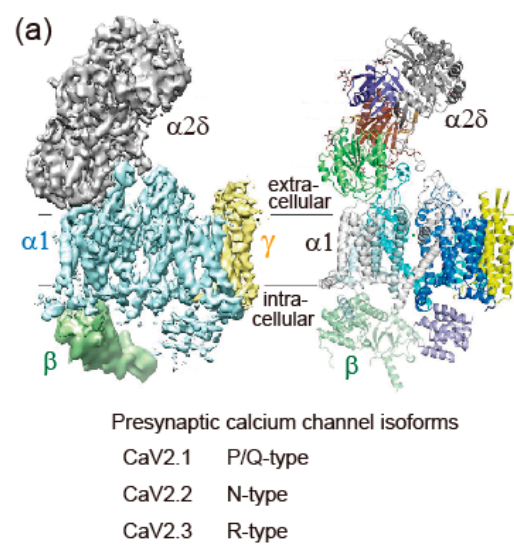

Figure 1. $\mathrm{Ca}^{2+}$ channel structure and organization. (a) The subunit composition and structure of high-voltage-activated $\mathrm{Ca}^{2+}$ channels. The cryo-EM structure of the rabbit voltage-gated $\mathrm{Ca}^{2+}$ channel Cav1.1 complex at a nominal resolution of $4.2 \AA$. The overall EM density map on the left is colored according to different subunits. The structure model on the right is color-coded for distinct subunits. Reproduced from [12]. (b) The $\alpha 1$ subunit consists of four homologous domains (I-IV), each consisting of six transmembrane segments (S1-S6). S1-S4 represents the voltage-sensing module. S5-S6 represents the pore-forming unit. The large intracellular loops linking the different domains of the $\alpha 1$ subunit serve as sites of interaction of different regulatory proteins important for channel regulation, including G-protein $(G \beta \gamma, G \alpha)$, RIM, SNARE proteins, and synaptotagmin at the synprint site (shown in green bar), calmodulin (CaM), and neuronal $\mathrm{Ca}^{2+}$ sensor proteins (nCaS) at the IQ-like motif, which begins with the sequence isoleucine-methionine (IM) instead of isoleucine-glutamine (IQ) and the nearby downstream CaM-binding domain (CBD), calmodulin kinase II (CaMKII), and protein kinase C (PKC). Adapted from [4].

$\mathrm{Ca}^{2+}$ channel $\alpha 1$ subunits are encoded by ten distinct genes in mammals, which are divided into three subfamilies by sequence similarity $[2,8,13]$. The $\mathrm{Ca}_{\mathrm{V}} 2$ subfamily members $\mathrm{Ca}_{\mathrm{V}} 2.1, \mathrm{Ca}_{\mathrm{V}} 2.2$, and Cav2.3 channels conduct P/Q-type, N-type, and R-type Ca ${ }^{2+}$ currents, respectively $[2,8,9,13]$.

$\mathrm{Ca}_{\mathrm{V}}$ channels are complexes of a pore-forming $\alpha 1$ subunit and auxiliary subunits. Skeletal muscle $\mathrm{Ca}_{V}$ channels have three distinct auxiliary protein subunits [8] (Figure 1a), the intracellular $\beta$ subunit, the disulfide-linked $\alpha 2 \delta$ subunit complex, and the $\gamma$ subunit having four transmembrane segments. In contrast, brain neuron $\mathrm{Ca}_{\mathrm{V}} 2$ channels are composed of the pore-forming $\alpha 1$ and the auxiliary $\beta$ subunit [14]. The auxiliary subunits of $\mathrm{Ca}^{2+}$ channels have an important influence on their function $[15,16]$. The $\mathrm{Ca}_{\mathrm{V}} \beta$ subunit shifts their kinetics and voltage dependence of activation and inactivation $[15,16]$. Cell surface expression of the $\alpha 1$ subunits is enhanced by the $\mathrm{Ca}_{\mathrm{V}} \beta$ subunit $[15,16]$. The $\alpha 2 \delta$ subunits are potent modulators of synaptic transmission. The $\alpha 2 \delta$ subunits increase not only $\mathrm{Ca}_{\mathrm{v}} 1.2$ but also $\mathrm{Ca}_{\mathrm{v}} 2.2, \mathrm{Ca}_{\mathrm{v}} 2.1$ currents, suggesting that the $\alpha 2 \delta$ subunits enhance trafficking of the $\mathrm{Ca}_{\mathrm{V}}$ channel complex [17]. Expression of $\alpha 2 \delta$ subunits also appears to play a role in setting release probability [18]. Further details of these regulatory interactions are discussed below. 


\section{Intracellular Molecules Modulate Presynaptic $\mathrm{Ca}^{2+}$ Channels Activity}

\subsection{G Proteins}

Presynaptic $\mathrm{Ca}^{2+}$ currents are reduced in magnitude by activation of $\mathrm{G}$ protein-coupled receptors for neurotransmitters at nerve terminals $[19,20]$. $G \beta \gamma$ subunits released from heterotrimeric $G$ proteins of the $\mathrm{Gi} / \mathrm{Go}$ class $[19,20]$ bind directly to $\alpha 1$ subunits of the $\mathrm{N}$-type $\mathrm{Ca}^{2+}$ channel $[21,22]$ at the $\mathrm{N}$ terminus [23], the intracellular loop connecting domains I and II [21,24], and at the C terminus [25] (Figure 1b). G $\beta \gamma$ causes a positive shift in the voltage dependence of activation of the $\mathrm{Ca}^{2+}$ current [26-28]. The G $\beta \gamma$-induced reduction of $\mathrm{Ca}^{2+}$ currents can be reversed by strong positive depolarization [26-28]. Reversal of this inhibition by depolarization provides a point of intersection between chemical and electrical signal transduction at the synapse and can potentially provide novel forms of short-term synaptic plasticity that do not rely on residual $\mathrm{Ca}^{2+}$.

The subtype of $\mathrm{Ca}_{V} \beta$ can influence the extent and kinetics of $\mathrm{G} \beta \gamma$ mediated inhibition and this regulation also depends on the subtype of $G \beta$ involved [29,30]. G $\beta \gamma$ interacts with multiple sites on the N-terminus, I-II linker, and the C-terminus of the $\alpha 1$ subunit. Binding of G $\beta \gamma$ causes a conformational shift that promotes interaction of the N-terminus "inhibitory module" with the initial one-third of the I-II-linker. Strong membrane depolarization leads to unbinding of $\mathrm{G} \beta \gamma$ and loss of interaction between the N-terminus and the I-II linker. This depends upon binding of $\mathrm{Ca}_{V} \beta$ subunit to the $\alpha$ interaction domain (AID) on the I-II linker. In the absence of $\mathrm{Ca}_{\mathrm{V}} \beta 1$ subunit binding with tryptophan mutation in the AID (W391) of the $\mathrm{Ca}_{\mathrm{V}} 2.2 \alpha 1$ subunit, $\mathrm{Ca}^{2+}$ channel inhibition still occurs but cannot be reversed by strong depolarization. $\mathrm{Ca}_{\mathrm{V}} \beta 2 \mathrm{a}$, that is palmitoylated at two $\mathrm{N}$-terminal cysteine residues, can still bind to the $\alpha 1$ subunit and permit voltage-dependent relief of the inhibition [31]. It is possible that binding of $\mathrm{Ca}_{\mathrm{V}} \beta 1$ to the AID induces a rigid $\alpha$-helical link with domain IS6, and this transmits the movement of the voltage-sensor and activation gate to the I-II linker to alter the G $\beta \gamma$ binding pocket at depolarized potentials [32].

Specific $\mathrm{G} \beta$ subunits have been shown to be responsible for the $\mathrm{Ca}_{\mathrm{V}} 2$ channel modulation in different neurons. In rat SCG neurons $\mathrm{Ca}_{\mathrm{V}} 2.2$ channels are differentially modulated by different types of $G \beta$ subunits, with $G \beta_{1}$ and $G \beta_{2}$ being most effective, $G \beta_{5}$ showing weaker modulation, and $G \beta_{3}$ and $G \beta_{4}$ being ineffective [33-35]. In contrast, in rat stellate ganglion neurons, $G \beta_{2}$ and $G \beta_{4}$ but not $\mathrm{G} \beta_{1}$ subunit are responsible for the coupling of $\mathrm{Ca}_{\mathrm{V}} 2.2$ channels with noradrenaline receptors [36]. In the transfected human embryonic kidney tsA-201 cell line, Cav 2.2 channel inhibition, with G $\beta_{1}$ and $G \beta_{3}$ being more effective than $G \beta_{4}$ and $G \beta_{2}$, and no significant modulation being induced by $G \beta_{5}$ [37]. $G \beta$ subunit-induced inhibition of $C_{V} 2.1$ channel differed from those observed with the $\mathrm{Ca}_{V} 2.2$ channel. $\mathrm{Ca}_{\mathrm{V}} 2.1$ channels exhibited more rapid rates of recovery from inhibition than those observed with $\mathrm{Ca}_{\mathrm{V}} 2.2$ channels, on average, twice as rapidly for the $\mathrm{Ca}_{\mathrm{V}} 2.1$ channels, indicating that $\mathrm{G} \beta$ binding to this channel subtype is less stable [37].

Regulation of the $\mathrm{Ca}_{\mathrm{V}} 2.2$ channels also involves the interplay between $\mathrm{Ca}^{2+}$ channels and $\mathrm{G}$ protein interaction. Syntaxin-1A, a presynaptic plasma membrane protein, is required for $\mathrm{G}$ protein inhibition of presynaptic $\mathrm{Ca}^{2+}$ channels [38]. Physical interaction between syntaxin-1A and $\mathrm{Ca}^{2+}$ channels is a prerequisite for tonic $\mathrm{G} \beta \gamma$ modulation of $\mathrm{Ca}_{\mathrm{V}} 2.2$ channels, suggesting that syntaxin-1A mediates a colocalization of $\mathrm{G} \beta \gamma$ subunits and $\mathrm{Ca}_{\mathrm{V}} 2.2$ channels, thus resulting in a more effective $\mathrm{G}$ protein coupling to, and regulation of, the channel. The interactions between syntaxin, $G$ proteins, and $\mathrm{Ca}_{V} 2.2$ channels are part of the structural specialization of the presynaptic terminal [39].

$\mathrm{G}$ proteins also induce voltage-independent inhibition of $\mathrm{Ca}_{\mathrm{V}} 2$ channels through intracellular signaling pathways $[1,19,40]$. This often involves the $\mathrm{Gq}$ family of $\mathrm{G}$ proteins, which regulate the levels of phosphatidylinositide lipids by inducing hydrolysis of phosphatidylinositol bisphosphate via activation of phospholipase $C$ enzymes [41]. Acetylcholine release from rat sympathetic neurons is reduced through this pathway via presynaptic muscarinic receptors activation [42]. 


\subsection{Active Zone Proteins}

Rab-interacting molecule (RIM), an AZ protein required for SVs docking and priming [43-48], and synaptic plasticity [49], interacts with the C-terminal cytoplasmic tails of Cav2.1 and Cav2.2 channels $[46,48,50,51]$ (Figure 1b). The interaction is essential for recruiting $\mathrm{Ca}^{2+}$ channels to the presynaptic AZ [46] and determines channel density and SVs docking at the presynaptic AZ [48]. RIM-binding proteins, RIM-BPs, also interact with $\mathrm{Ca}_{V} 2.1$ and $\mathrm{Cav}_{\mathrm{V}} 2.2$ channels [51], and are selectively required for high-fidelity coupling of AP-induced $\mathrm{Ca}^{2+}$ influx to $\mathrm{Ca}^{2+}$-stimulated SVs exocytosis [52]. The tripartite complex of RIM, RIM-BPs, and C-terminal tails of the $\mathrm{Ca}_{\mathrm{V}} 2$ channels regulate the recruitment of $\mathrm{Ca}_{\mathrm{V}} 2$ channels to AZs. Interaction of RIM with $\mathrm{Ca}_{\mathrm{V}} \beta$ subunits shifts the voltage dependence of inactivation to more positive membrane potentials, increasing $\mathrm{Ca}^{2+}$ channel activity [53]. In contrast, $\mathrm{Ca}_{\mathrm{V}} \beta$ subunits interaction with CAST/ERC2 shifts the voltage dependence of activation to more negative membrane potentials [54]. Positive regulation of presynaptic $\mathrm{Ca}^{2+}$ channel activity by RIM and CAST/ERC2, in addition to their function in SVs docking, increase the release probability of SVs docked close to Cav2 channels. Furthermore, Munc13, required for SVs priming, controls Cav2 channels shortly after AP firing to guarantee transmitter release for continuous neural activity [55].

\section{3. $t$-SNAREs and Synaptotagmin-1}

SV (v)-SNARE synaptobrevin 2 and presynaptic plasma membrane (t)-SNAREs syntaxin-1 and SNAP-25 are required for fusion of SVs with a plasma membrane to release neurotransmitters [56]. Both $\mathrm{Ca}_{\mathrm{V}} 2.1$ and $\mathrm{Ca}_{\mathrm{V}} 2.2$ channels at the presynaptic nerve terminals colocalize densely with syntaxin-1A [57-59], and also form a complex of with SNARE proteins [60-62] dependent on $\mathrm{Ca}^{2+}$ with maximal binding at $20 \mu \mathrm{M}$ and reduced binding at lower or higher concentrations of $\mathrm{Ca}^{2+}[63]$. The t-SNARE proteins syntaxin-1A and SNAP-25, but not the v-SNARE synaptobrevin, bind to the intracellular loop between domains II and III of the $\alpha_{1}$ subunit of $\mathrm{Ca}_{\mathrm{V}} 2.2$ (amino acid residues 718-963) named as the synprint site (Figure 1b) $[64,65] . \mathrm{Ca}_{\mathrm{V}} 2.1$ channels have an analogous synprint site, and different channel isoforms have distinct interactions with syntaxin and SNAP-25 [66,67], suggesting specialized regulatory properties for synaptic modulation.

t-SNAREs interacting with presynaptic $\mathrm{Ca}_{V} 2.1$ and $\mathrm{Ca}_{\mathrm{V}} 2.2$ channels regulate channel activity (Figure 3a). Syntaxin-1A or SNAP-25 shifts the voltage dependence of inactivation toward more negative membrane potentials and reduces the availability of the channels to open [68-70]. Coexpression of SNAP-25 can reverse the inhibitory effects of syntaxin-1A [69,71]. The transmembrane region of syntaxin-1A and only a short segment within the H3 helix are critical for channel modulation [72], whereas the synprint site binds to the entire $\mathrm{H} 3$ helix in the cytoplasmic domain of syntaxin-1A [63,64,72]. Deletion of the synprint site weakened the modulation of the channels by syntaxin-1A, but did not abolish it, arguing that the synprint site acts as an anchor in facilitating channel modulation but is not required absolutely for modulatory action.

Dependent on $\mathrm{Ca}^{2+}$ concentration, syntaxin-1 interacts with either the synprint site or synaptotagmin-1; at low $\mathrm{Ca}^{2+}$ concentrations, syntaxin-1 binds synprint, while at higher concentrations $(>30 \mu \mathrm{M})$ it associates with synaptotagmin-1 [63]. Synaptotagmin-1, -2 , and -9 serve as the $\mathrm{Ca}^{2+}$ sensors for the fast, synchronous neurotransmitter release $[56,73,74]$. The $\mathrm{Ca}^{2+}$ binding site $\mathrm{C} 2 \mathrm{~B}$ domain of synaptotagmin- 1 interacts with the synprint sites of both $\mathrm{Ca}_{\mathrm{V}} 2.1$ and $\mathrm{Ca}_{\mathrm{V}} 2.2$ channels (Figure 1b) [75]. Synaptotagmin- 1 can relieve the inhibitory effects of SNAP- 25 on Cav 2.1 channels $[70,76]$. Relief of $\mathrm{Ca}^{2+}$ channel inhibition by the formation of the synaptotagmin/SNARE complex favors $\mathrm{Ca}^{2+}$ influx. This is a potential mechanism to increase the release probability of SVs docked close to Cav 2 channels [4].

Interaction of syntaxin-1A and SNAP-25 with the synprint site is controlled by phosphorylation of the synprint site with protein kinase $\mathrm{C}$ (PKC) (Figure 1b) [65] and $\mathrm{Ca}^{2+} /$ calmodulin-dependent protein kinase II (CaMKII) [77]. The negative shift of steady-state inactivation of $\mathrm{Ca}_{\mathrm{V}} 2.2$ channels caused by syntaxin is blocked by PKC phosphorylation $[65,71]$. Thus, phosphorylation of the synprint site may serve as a biochemical switch controlling the SNARE-synprint interaction. 


\section{4. $\mathrm{Ca}{ }^{2+}-$ Sensor Proteins}

$\mathrm{Ca}^{2+}$ elevation regulates $\mathrm{Ca}_{v} 2.1$ channels activity by its binding to $\mathrm{CaM}[8,78-81]$ and related neuron-specific $\mathrm{Ca}^{2+}$-binding proteins, CaBP1, VILIP-2 [82-84], and NCS-1 (frequenin) [85]. The presynaptic $\mathrm{Ca}_{V} 2.1$ channel proteins consist of a pore-forming $\alpha_{1}$ subunit associated with $\beta$, and possibly $\alpha_{2} \delta$ subunits (Figure 1a) [86]. The intracellular C terminus of the $\alpha 1$ subunit [81] called the IQ-like motif, which begins with the sequence isoleucine-methionine (IM) instead of isoleucine-glutamine (IQ), and the nearby downstream CaM-binding domain (CBD) are the interacting sites with these $\mathrm{Ca}^{2+}$-binding proteins (Figure $1 \mathrm{~b}$ ). Displacement with alanine in the IQ-like domain inhibited $\mathrm{Ca}^{2+}$-dependent $\mathrm{Ca}_{\mathrm{V}} 2.1$ channels facilitation [78,81], whereas deletion of CBD inhibited $\mathrm{Ca}^{2+}$-dependent Cav2.1 channels inactivation [79-81,83,84]. $\mathrm{Ca}^{2+} / \mathrm{CaM}$-dependent inactivation of $\mathrm{Ca}_{\mathrm{V}} 2.1$ channels, dependent on global elevations of $\mathrm{Ca}^{2+}$, is observed in transfected cells overexpressing Cav 2.1 channels [78-80] and in the nerve terminals of the calyx of Held $[87,88]$ where Cav 2.1 channels are densely localized. In contrast, the large neuronal cell bodies of Purkinje neurons [89] or SCG neurons [90] rarely show $\mathrm{Ca}^{2+}$-dependent $\mathrm{Ca}_{\mathrm{V}} 2.1$ channels inactivation.

\section{Negative Regulation of Neurotransmitter Release by G $\beta \gamma$ protein/Cav2 Channel Complex}

Receptor-activated $\mathrm{G} \beta \gamma$ modulation of presynaptic $\mathrm{Ca}_{V} 2$ channels is a potent negative regulation of neurotransmitter release. Electrophysiological recordings of $\mathrm{Ca}^{2+}$ currents and synaptic transmission at the calyx of Held demonstrated this type of negative regulation by activation of GABA-B receptors or metabotropic glutamate receptors [91,92]. Optical measurements of $\mathrm{Ca}^{2+}$ transients at the nerve terminals of the parallel fibers of cerebellar granule cells innervating Purkinje neurons has also demonstrated similar modulation by activation of CB1 receptors [93]. This G $\beta \gamma$-mediated inhibition of $\mathrm{Ca}^{2+}$ channels is relieved by depolarization. At autapses formed by single hippocampal pyramidal neurons, trains of AP-like stimuli relieve the inhibition of synaptic transmission caused by activation of GABA-B receptors, resulted in facilitation of synaptic transmission, which was blocked by inhibition of $\mathrm{Ca}_{\mathrm{V}} 2.1$ channels with neurotoxins [94]. Thus, presynaptic firing could reverse the neurotransmitter-mediated $G$ protein inhibition of synaptic transmission. Regulator of $G$ protein signaling-2 (RGS-2), which speeds GTPase activity of the $\alpha$ subunit of the activated G protein $\alpha$-GTP, determines short-term plasticity in hippocampal neurons by regulating Gi/o-mediated inhibition of presynaptic $\mathrm{Ca}^{2+}$ channels. RGS-2 relieves the inhibition, resulting in a higher basal probability of release and synaptic facilitation [95]. However, at parallel fibers synapses onto Purkinje cells, this form of facilitation is not responsible for short-term synaptic plasticity [96].

In SCG neurons noradrenaline shortens AP duration by reducing $\mathrm{Ca}^{2+}$ entry through $\mathrm{Ca}_{\mathrm{v}} 2.2$ channels, resulting in a reduction of transmitter release [97]. Purified $G \beta \gamma$ microinjected into presynaptic SCG neurons in culture reduced synaptic transmission, and the G $\beta \gamma$ introduced neurons caused no further reduction of synaptic transmission with noradrenaline [97]. Thus, G $\beta \gamma$ is a potent negative regulator of neurotransmission inhibiting presynaptic $\mathrm{Ca}_{\mathrm{V}} 2.2$ channels activity. The $\alpha 1$ subunit contains several G $\beta \gamma$ interaction sites, including the amino-terminal (NT) and I-II loop (Figure 1b). The "NT peptide" and an I-II loop $\alpha$ interaction domain "AID peptide" microinjected into presynaptic SCG neurons under long-term culture attenuated noradrenaline-induced $G$ protein modulation (Figure 2) and inhibited synaptic transmission [98]. In acutely dissociated SCG neurons, NT and AID peptides reduced whole-cell $\mathrm{Ba}^{2+}$ current amplitude, modified voltage dependence of $\mathrm{Ca}^{2+}$ channel activation, and attenuated noradrenaline-induced G protein modulation (Figure 2) [98]. Co-application of NT and AID peptide negated inhibitory actions. Furthermore, a mutation within NT abolished inhibitory effects of the NT peptide [98]. Effects of $\mathrm{Ca}_{\mathrm{V}} 2.2$ channel peptides demonstrate that the $\mathrm{Ca}_{\mathrm{V}} 2.2$ amino-terminal and I-II loop serve as molecular determinants for $\mathrm{Ca}^{2+}$ channel function to inhibit synaptic transmission and to attenuate $G$ protein modulation. 

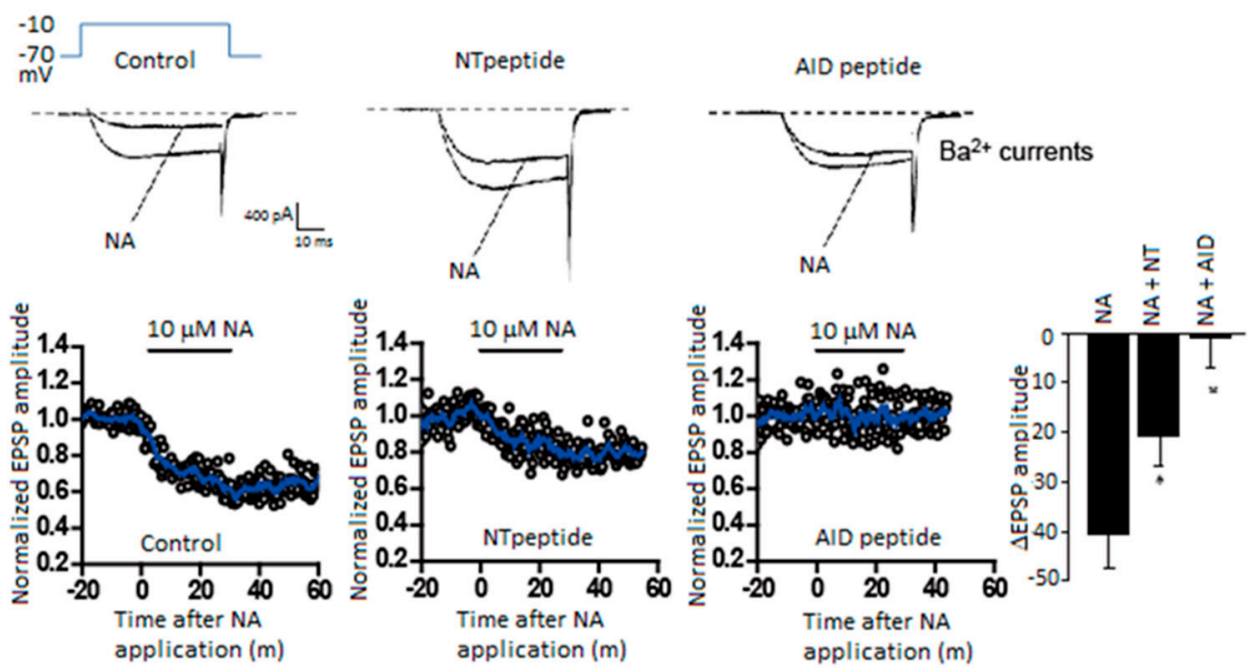

Figure 2. G $\beta \gamma$-mediated noradrenaline inhibition of transmitter release and N-terminal/I-II loop AID peptides of $\mathrm{Ca}_{\mathrm{V}} 2.2 \alpha 1$-subunit. Noradrenaline (NA) induced $\mathrm{Ba}^{2+}$ current inhibition (upper traces) and transmitter release (lower graphs) were attenuated in the presence of $G \beta \gamma$-interaction site of $N$-terminal peptide $\left(\mathrm{Ca}_{\mathrm{V}} 2.2^{45-55}\right.$, YKQSIAQRART) or AID peptide $\left(\mathrm{Ca}_{\vee}{ }^{377-393}\right.$, RQQQIEREL NGYLEWIF) (See Figure $1 \mathrm{~b}$ ). $\mathrm{Ba}^{2+}$ currents were recorded from superior cervical ganglion (SCG) neurons acutely dissociated from 3- to 6-week-old Wistar rats, while the synaptic transmission was recorded from long-term cultured SCG neurons isolated from $\mathrm{p} 7 \mathrm{rat}$. NA was bath-applied $30 \mathrm{~min}$ after injection of the peptide at $1 \mathrm{mM}$ in the injection pipette. EPSPs were normalized to amplitude prior to NA application at time $=0 \mathrm{~min}$. Bar graph summarizing NA effects, ${ }^{*} p<0.05 v s$. NA effects in controls (Student's $t$-test). Adapted from [98].

\section{Synchronous Neurotransmitter Release Regulated by $\mathrm{Ca}^{2+}$ Channel/SNARE Proteins Complex}

Synprint peptides derived from $\mathrm{Ca}_{\mathrm{V}} 2.2$ channels reduced transmitter release from the microinjected presynaptic SCG neurons in culture, due to competitive uncoupling of the endogenous $\mathrm{Ca}^{2+}$ channel-SNARE proteins interaction in nerve terminals [99]. Synprint peptides selectively inhibited fast synchronous synaptic transmission, while they increased late asynchronous release (Figure 3b). Similarly, synprint peptides reduced transmitter release from embryonic Xenopus spinal neurons [100]. Increasing the external $\mathrm{Ca}^{2+}$ concentration effectively rescued this inhibition, implying that synprint peptides competitively displaces docked SVs away from $\mathrm{Ca}^{2+}$ channels, and this effect can be overcome by increasing $\mathrm{Ca}^{2+}$ influx into presynaptic terminals [100].

At the calyx of Held, presynaptic neurons express P/Q-, N- and R-type $\mathrm{Ca}^{2+}$ currents in postnatal day 7 rats. P/Q-type $\mathrm{Ca}^{2+}$ currents are more effective than $\mathrm{N}$-type $\mathrm{Ca}^{2+}$ currents and R-type $\mathrm{Ca}^{2+}$ currents in eliciting neurotransmitter release [101-103]. The high efficiency of P/Q-type $\mathrm{Ca}^{2+}$ currents to initiate neurotransmitter release is correlated with the close localization of $\mathrm{Ca}_{\mathrm{V}} 2.1$ channels near docked SVs [104], as shown by immunocytochemistry [105], suggesting localization of $\mathrm{Ca}_{\mathrm{V}} 2$ channels determines the efficiency of neurotransmitter release in response to neural activity.

$\mathrm{Ca}_{V} 2$ channels interaction with SNARE proteins, that is dependent on $\mathrm{Ca}^{2+}$ concentration [63], have two opposing effects: at the pre-firing state synaptic transmission is blocked by enhancing $\mathrm{Ca}_{\mathrm{V}} 2$ channels inactivation, whereas immediately after AP firing tethering SVs near the point of $\mathrm{Ca}^{2+}$ entry enhances synaptic transmission. The overexpression of a syntaxin mutant that is unable to regulate $\mathrm{Ca}_{V} 2.2$ channels, but still binds to them [72], increased the efficiency of synaptic transmission at Xenopus neuromuscular junctions, as reflected in increased quantal content [106]. In contrast, injected synprint peptides reduced the basal efficiency of synaptic transmission, as reflected in reduced quantal content of synaptic transmission [106]. These results demonstrate a bidirectional regulation of synaptic transmission in vivo by interactions of $\mathrm{Ca}_{\mathrm{V}} 2.2$ channels with SNARE proteins. 
(a)

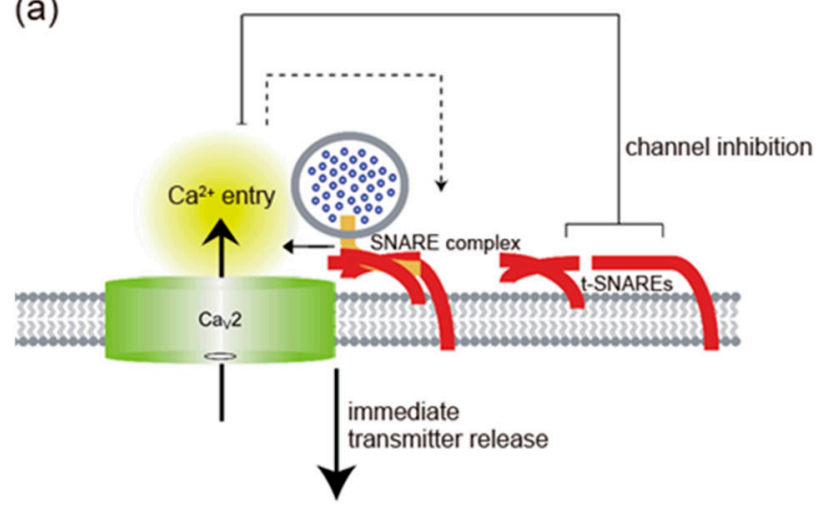

(b)

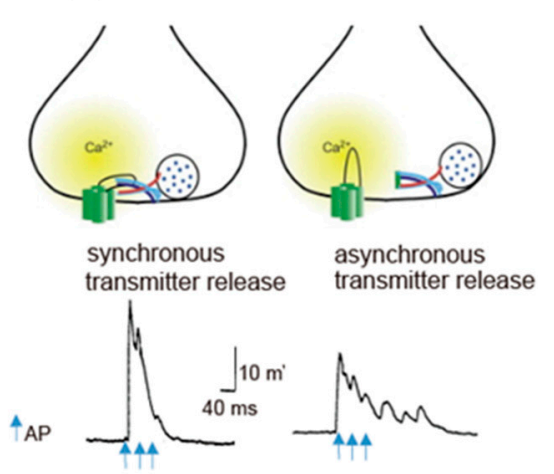

Figure 3. Spatial regulation of transmitter release by the I-II loop interaction with SNAREs. (a) The I-II loop interacts with t-SNAREs, resulting in inhibition of Ca2.2 channels opening. Once AP opens the channels, an increase in $\mathrm{Ca}^{2+}$ mediates interaction with SNAREs complex and induces transmitter release. Adapted from [4]. (b) Triple APs induces a large synchronous transmitter release from the first AP. In contrast, asynchronous transmitter release was observed in the presence of $130 \mu \mathrm{M}$ synprint peptide (see Figure 1b). Adapted from [99].

\section{Presynaptic Plasticity Induced by $\mathrm{Ca}^{2+}$-Sensors-Mediated Cav2.1 Channel Modulation}

At most fast synapse in the central nervous system, $\mathrm{Ca}_{\mathrm{V}} 2$ channels are expressed diversely. In contrast, synaptic transmission of long-term cultured sympathetic SCG neurons, forming a well-characterized cholinergic synapse $[107,108]$, is mediated by $\mathrm{Ca}_{\mathrm{V}} 2.2$ channels $[109,110]$. The physiological role of presynaptic $\mathrm{Ca}_{\mathrm{V}} 2.1$ channel modulation by $\mathrm{Ca}^{2+}$-sensors was explored by exogenously expressed $\alpha 1$ subunit derived from the brain $\mathrm{Ca}_{V} 2.1$ channel that functionally generates $\mathrm{P} / \mathrm{Q}$ type currents with other endogenous subunits in SCG neuron [111]. Section 6 describes presynaptic plasticity induced by modulation of the $\mathrm{Ca}_{\mathrm{V}} 2.1$ channel that is mediated by $\mathrm{CaM}$ or expression of neuron-specific $\mathrm{Ca}^{2+}$-sensor proteins, monitoring excitatory postsynaptic potentials (EPSPs) evoked by various patterns of presynaptic APs firing in the presence of the blocker of endogenous $\mathrm{Ca}_{\mathrm{V}} 2.2$ channels [109].

\section{1. $\mathrm{Ca}^{2+} / \mathrm{CaM}$ Mediates Synaptic Depression and Facilitation}

Modulation of presynaptic $\mathrm{Ca}^{2+}$ channels has a powerful influence on synaptic transmission [90]. The cytoplasmic regions of the $\alpha 1$ subunit are the target of regulatory proteins for channel modulation (Figure 1B). Brain-derived $\alpha 1$ subunit of the $\mathrm{Ca}_{\mathrm{V}} 2.1$ channel mediates transmitter release from the transfected SCG neurons [111]. The transmitter release changes after AP firing due to modulation of $\mathrm{Ca}_{V} 2.1$ channel interacting with $\mathrm{Ca}^{2+}$ bound $\mathrm{CaM}$ (Figure 4) [90]. CaM has two $\mathrm{Ca}^{2+}$ binding sites, $\mathrm{N}$ and $\mathrm{C}$ robes. The $\mathrm{N}$-robe sensing rapid and higher increase in $\mathrm{Ca}^{2+}$ concentration [112] initiates synaptic depression, and following facilitation is mediated by the $\mathrm{C}$-robe sensing lower $\mathrm{Ca}^{2+}$ concentration. EPSPs recorded by pairs of APs with varied stimulation intervals show paired-pulse depression (PPD) and facilitation (PPF) (Figure 4a). PPD with a short interval ( $<50 \mathrm{~ms})$ was blocked by deletion of the CBD, while PPF with intermediate interval (50-100 ms) was blocked by mutation of the IQ-like motif. Thus, the decline in $\mathrm{Ca}^{2+}$ elevation after the first AP causes temporal regulation of the $\mathrm{Ca}_{\mathrm{V}} 2.1$ channel interacting with $\mathrm{CaM}$, resulting in a change in the transmitter release efficacy (Figure $4 \mathrm{~b}$ ). The time-dependent opposing modulation of the $\mathrm{Ca}_{\mathrm{V}} 2.1$ channel activity may support a stable synaptic transmission.

Neural information in vivo is encoded in bursts of AP firing. Short-term presynaptic plasticity caused by APs bursts involves the CaM-dependent regulation of $\mathrm{Ca}_{\mathrm{V}} 2.1$ channel. Mutation of the IQ-like motif potentiated reduction of the release efficacy, whereas the deletion of the CBD increased the release efficacy (Figure $4 c$, IM-AA/ $\triangle C B D$ ). Thus, during APs bursts, CaM binding to the CBD controls negatively the release efficacy, whereas CaM binding to IQ-like motif controls it positively. At 
a higher frequency of APs burst over $20 \mathrm{~Hz}$, the release efficacy of SCG neurons mediated by Ca 2.1 channels reduced gradually (Figure 4c, WT), suggesting that the CaM-dependent inactivation of $\mathrm{Ca}_{\mathrm{V}} 2.1$ channels shapes the time course of short-term synaptic plasticity by determining the timing of the peak of synaptic facilitation during APs bursts as well as the steady-state level of synaptic depression at the end of the APs bursts.

(a)

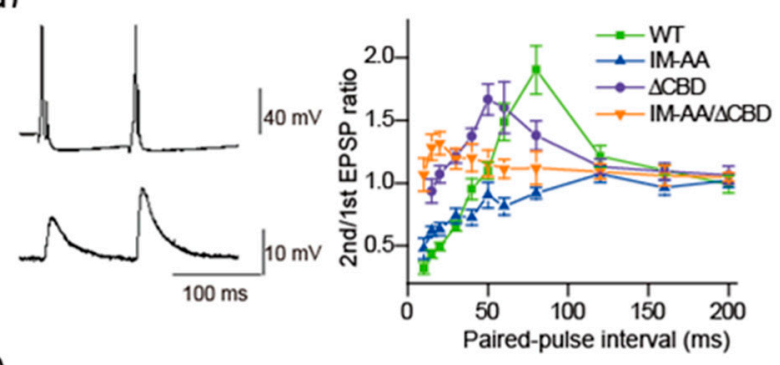

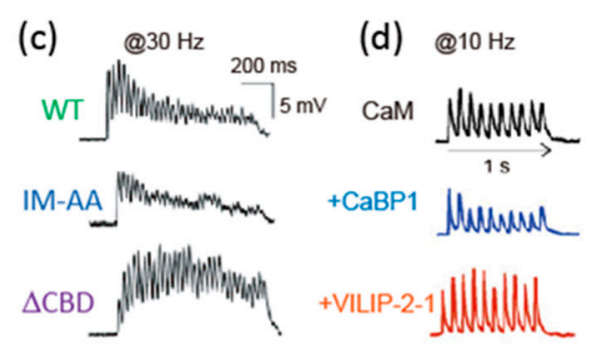

(b)

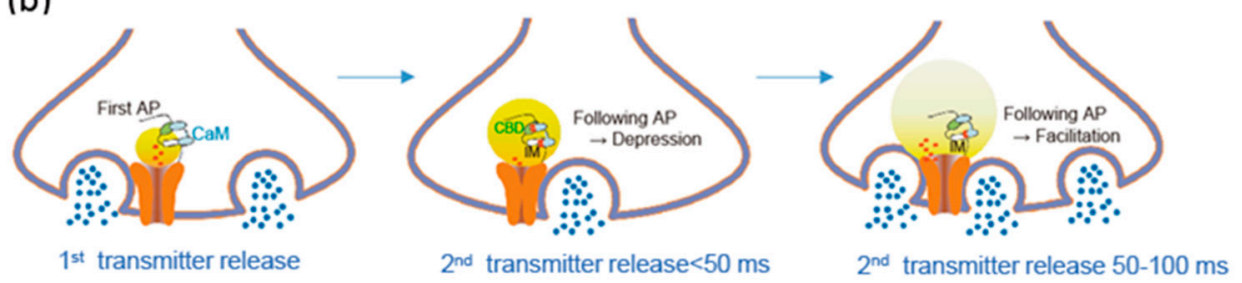

Figure 4. Temporal regulation of $\mathrm{Ca}^{2+}$ channel activity by CaM and $\mathrm{nCaS}$ after $\mathrm{AP}(\mathrm{s})$ firing modulates synaptic transmission. (a) Regulation of transmitter release (lower trace) after an AP firing (upper trace). Dependent on the inter-stimulus interval the second AP induces paired-pulse depression (PPD) and facilitation (PPF). The PPD was prevented by $\triangle \mathrm{CBD}$, while PPF was prevented by IM-AA mutation of Cav2.1 channels. (b) Model for $\mathrm{Ca}^{2+} / \mathrm{CaM}$-dependent inactivation and facilitation of $\mathrm{Ca}^{2+}$ channels and neurotransmitter release. (c) Biphasic synaptic transmission during 1-s train of APs at $30 \mathrm{~Hz}$ changed to synaptic depression by the IM-AA mutation or to synaptic facilitation by the $\triangle \mathrm{CBD}$. (d) Overexpression of CaBP1 (blue) blocks synaptic facilitation, while overexpression of VILIP-2 (red) blocks synaptic depression, during 1-s train of APs at $10 \mathrm{~Hz}$. Adapted from [90] (a-c) and [113] (d).

\subsection{Neuron-Specific Ca ${ }^{2+}$-Sensor Proteins Mediate Synaptic Depression and Facilitation}

CaBP1, VILIP-2, and NCS-1 are members of a subfamily of neuron-specific $\mathrm{Ca}^{2+}$-sensor proteins (nCaS) that possess four EF-hand $\mathrm{Ca}^{2+}$-binding motifs. CaBP-1, VILIP-2, and NCS-1 bind to the same site as $\mathrm{CaM}$, and modulate $\mathrm{Ca}_{\mathrm{V}} 2.1$ channel activity. CaBP1, highly expressed in the brain and retina [114], causes rapid inactivation of $\mathrm{Ca}_{\mathrm{V}} 2.1$ channels, binding to the CBD [84]. VILIP-2, highly expressed in the neocortex and hippocampus [115], increases $\mathrm{Ca}^{2+}$-dependent facilitation of $\mathrm{Ca}_{\mathrm{V}} 2.1$ channels but inhibits $\mathrm{Ca}^{2+}$-dependent inactivation of $\mathrm{Ca}_{\mathrm{V}} 2.1$ channels, binding to both IQ-like motif and CBD [83]. NCS-1, the classical example of facilitation of synaptic activity by nCaS, reduces $\mathrm{Ca}^{2+}$-dependent inactivation of $\mathrm{P} / \mathrm{Q}$-type $\mathrm{Ca}^{2+}$ currents through interaction with the IQ-like motif and $\mathrm{CBD}$ without affecting peak current or activation kinetics [85].

Synaptic transmission of SCG neurons transfected with CaBP1 and VILIP-2 changed by their modulation of $\mathrm{Ca}_{V} 2.1$ channels with binding residual $\mathrm{Ca}^{2+}$ [113]. APs burst at $10 \mathrm{~Hz}$ induces synaptic facilitation followed by synaptic depression due to endogenous CaM. CaBP1 coexpressed with $\mathrm{Ca}_{\mathrm{V}} 2.1$ channels, significantly reduced the synaptic facilitation and enhanced the synaptic depression (Figure 4d) [113]. In contrast, VILIP-2 coexpressed with $\mathrm{Ca}_{\mathrm{V}} 2.1$ reduced the synaptic depression and enhanced the synaptic facilitation (Figure 4d) [113]. CaBP1 and VILIP-2 have opposing effects on short-term synaptic plasticity, either favoring synaptic depression or facilitation, suggesting that nCaS via regulation of presynaptic $\mathrm{Ca}^{2+}$ channels may play a critical role in determining the diversity of short-term synaptic plasticity at CNS synapses. 
The expression of NCS-1 in presynaptic SCG neurons does not affect synaptic transmission, eliminating effects of this nCaS on endogenous $\mathrm{N}$-type $\mathrm{Ca}^{2+}$ currents [85]. However, in SCG neurons expressing $\mathrm{Ca}_{\mathrm{V}} 2.1$ channels, coexpression of NCS-1 induces facilitation of synaptic transmission in response to paired APs and trains of APs, and this effect is lost in Cav2.1 channels with mutations in the IQ-like motif and CBD [85]. These results reveal that NCS-1 directly modulates Cav2.1 channels to induce short-term synaptic facilitation, and further demonstrate that $\mathrm{nCaS}$ are crucial in fine-tuning short-term synaptic plasticity.

\subsection{Temporal Regulation of Release Efficacy by $\mathrm{Ca}^{2+}$-Sensor Proteins}

The opening of $\mathrm{Ca}^{2+}$ channel creates a steep gradient of $\mathrm{Ca}^{2+}$ elevation in the $\mathrm{AZ}$, where each $\mathrm{nCaS}$ has a different affinity and binding speed to $\mathrm{Ca}^{2+}$ [112]. The affinity is CaM $(5-10 \mu \mathrm{M})>\mathrm{CaBP} 1$ $(2.5 \mu \mathrm{M})>\operatorname{VILIP}-2(\sim 1 \mu \mathrm{M})$ [116]. CaM has a lower affinity and a higher binding speed to $\mathrm{Ca}^{2+}$ than $\mathrm{nCaS}$, suggesting a temporal regulation of $\mathrm{Ca}_{\mathrm{V}} 2.1$ channel activity by CaM versus $\mathrm{nCaS}$. Their affinity and binding speed to $\mathrm{Ca}^{2+}$ determinate timing of the $\mathrm{Ca}_{\mathrm{V}} 2.1$ channel modulation. Thus differential effects of $\mathrm{CaM}$ and $\mathrm{nCaS}$ on facilitation and inactivation of the presynaptic $\mathrm{Ca}_{\mathrm{v}} 2.1$ channels would substantially change the encoding of the synaptic properties in response to bursts of APs firing [117].

Time window of the CaM- and nCaS-induced $\mathrm{Ca}_{\mathrm{V}} 2.1$ channel modulation after AP firing can be estimated by the paired-pulse protocol applying to SCG neurons transfected with Cav 2.1 channels. CaM mediated PPD with a short interval ( $<100 \mathrm{~ms})$, and PPF with intermediate interval (20-100 ms) (Figure 2a). In contrast, NCS-1 induced PPF with a shorter interval (30-50 ms) [85]. CaBP1 induced PPD with interval $<150 \mathrm{~ms}$, while VILIP-2 induced PPF with an interval of 50-250 ms [113]. These data suggest that $\mathrm{CaM}$ modulates $\mathrm{Ca}_{\mathrm{V}} 2.1$ channels shortly after $\mathrm{Ca}^{2+}$ entry and lasts $100 \mathrm{~ms}$, while NCS-1 acts much shorter and CaBP1 and VILIP-2 actions last longer than CaM effects. The time-dependent action of $\mathrm{CaM}$ and $\mathrm{nCaS}$ reflects the decline rate of $\mathrm{Ca}^{2+}$ concentration at the $\mathrm{Ca}_{\mathrm{V}} 2.1$ channels after an AP firing. The divergent actions of $\mathrm{CaM}$ and $\mathrm{nCaS}$ on $\mathrm{Ca}_{\mathrm{V}} 2.1$ channels fine-tune the function and regulatory properties of presynaptic $\mathrm{P} / \mathrm{Q}$-type $\mathrm{Ca}^{2+}$ currents, allowing a greater range of input-output relationships and causing various short-term plasticity at different synapses [4].

\subsection{CaMKII Saves as Effector Checkpoint for $\mathrm{Ca}^{2+}$ Entry}

CaMKII is the most prominent $\mathrm{Ca}^{2+} / \mathrm{CaM}$-dependent regulator of postsynaptic response [118-121] and presynaptic function [122-125]. The autophosphorylated form of CaMKII [7], which does not require the catalytic activity of the enzyme [126], binds to the $\alpha 1$ subunit of $\mathrm{Ca}_{\mathrm{V}} 2.1$ channels upstream of the IQ-like motif, and enhances the activity by slowing inactivation and positively shifting the voltage dependence of inactivation [126]. The dephosphorylation of CaMKII does not reverse the binding [127]. The presence of a competing peptide that blocks the interaction of CaMKII with presynaptic Cav2.1 channels of SCG neurons prevented both PPD and PPF, suggesting that binding of CaMKII to Cav2.1 channels is required for the expression of this regulatory effect. Similarly, the expression of the brain-specific CaMKII inhibitor CaMKIIN [128], which prevents CaMKII binding to Cav2.1 channels [126], also prevented PPD and PPF. Thus, the noncatalytic regulation of Cav2.1 channels by bound CaMKII controls the activity of those channels that have the effector of the $\mathrm{Ca}^{2+}$ signal (i.e., CaMKII) in position to bind the entering $\mathrm{Ca}^{2+}$ and respond to it [126]. SNARE proteins and RIM similarly serve as effectors of the $\mathrm{Ca}^{2+}$ signal for initiation of SVs exocytosis increasing the activity of the $\mathrm{Ca}_{\mathrm{V}} 2.1$ channels by the formation of a complete SNAREs complex with synaptotagmin and RIM bound $[53,70]$. This "effector checkpoint" mechanism serves to focus $\mathrm{Ca}^{2+}$ entry through those $\mathrm{Ca}^{2+}$ channels whose effectors are bound and ready to respond.

Furthermore, autophosphorylated CaMKII bound to $\mathrm{Ca}_{\mathrm{V}} 2.1$ channels also binds to synapsin-1, a phosphoprotein of the SVs, increases its phosphorylation and induces oligomers of synapsin-1 [127]. Synapsin-1 is a major presynaptic phosphoprotein that is a prominent substrate for CaMKII, and phosphorylation by CaMKII regulates the effects of synapsin-1 on the trafficking of SVs [129]. The phosphorylation of synapsin-1 by CaMKII increases synaptic transmission at the squid giant 
synapse [122,123]. Formation of the ternary complex of $\mathrm{Ca}_{\mathrm{V}} 2.1$ and synapsin- 1 bound to CaMKII would modulate the dynamics of SV function in AZs containing these proteins [127].

\section{Neuronal Firing and Presynaptic Short-Term Plasticity}

Neuronal firing regulates presynaptic $\mathrm{Ca}^{2+}$ channels by $\mathrm{Ca}^{2+}$ bound $\mathrm{CaM}$ and $\mathrm{nCaS}$ and causes facilitation and inactivation of neurotransmitter release. The differential expression of these $\mathrm{Ca}^{2+}$-dependent regulatory proteins may provide a means of cell-type-specific regulation of presynaptic $\mathrm{Ca}^{2+}$ channels and short-term synaptic plasticity. The short-term plasticity of neurotransmitter release shapes the postsynaptic response to bursts of impulses and is crucial for the fine-grained encoding of information in the nervous system $[117,130]$.

\subsection{Presynaptic Short-Term Facilitation}

The Calyx of Held, the large presynaptic terminal enabling to record directly presynaptic $\mathrm{Ca}^{2+}$ current by voltage-clamp methods, suggests that neuronal firing controls $\mathrm{P} / \mathrm{Q}-$ and $\mathrm{N}$-type currents to modulate differentially synaptic transmission. Presynaptic $\mathrm{Ca}^{2+}$ current consists of a combination of P/Q- and N-type currents in young mice and shows activity-dependent facilitation that predicts the amount of synaptic facilitation according to the power law [131,132]. Cav2.1 knockout lost both facilitation of the presynaptic $\mathrm{Ca}^{2+}$ current and synaptic facilitation [101,131,132]. The remaining N-type $\mathrm{Ca}^{2+}$ currents are less efficient in mediating synaptic transmission and do not support facilitation of synaptic transmission, but they are more sensitive to modulation by $G$ protein-coupled receptors [101] These results suggest that $\mathrm{Ca}_{\mathrm{V}} 2.1$ channels are responsible for neuronal activity-dependent synaptic facilitation, while $\mathrm{Ca}_{\mathrm{V}} 2.2$ channels have strong $\mathrm{G}$ protein regulation.

Presynaptic short APs bursts generate augmentation and longer APs bursts generate post-tetanic potentiation (PTP) relying on residual $\mathrm{Ca}^{2+}$. The optical measurement of presynaptic $\mathrm{Ca}^{2+}$ transients with the induction of PTP in the calyx of Held showed an increase in the $\mathrm{Ca}^{2+}$ influx to the extent that predicted PTP when the power law of neurotransmission was applied, and the $\mathrm{Ca}^{2+}$ transient decayed with a time course of the decay of PTP [133]. In Cav2.1-transfected SCG neurons, PTP was not significantly affected by mutations at the IQ-like motif [90]. In contrast, PPF and augmentation share a common mechanism involving an increase in instantaneous $\mathrm{Ca}^{2+}$ entry through $\mathrm{Ca}_{\mathrm{V}} 2.1$ channels by CaM- and nCaS-binding in an activity-dependent manner, which in turn facilitates neurotransmitter release. It is likely that facilitation of presynaptic $\mathrm{Ca}^{2+}$ currents may contribute to short-term facilitation [90,132], and the augmentation and the PTP represent overlapping processes caused by differential combinations of mechanisms at different synapses [130].

The expression of $\mathrm{Ca}_{\mathrm{V}} \beta$ subunits has a strong influence on synaptic facilitation in hippocampal synapses through their effects on $\mathrm{Ca}^{2+}$ channel function [134]. $\operatorname{Cav} \beta 2$ and $\operatorname{Cav} \beta 4$ subunits distribute in clusters and localize to synapses. Ca $\beta 2$ induces depression, whereas Cav $\beta 4$ induces PPF followed by synaptic depression during longer stimuli trains. The induction of PPF by Cav $\beta 4$ correlates with a reduction in the release probability and cooperativity of the transmitter release. These results suggest that $\operatorname{Cav} \beta$ subunits determine the gating properties of the presynaptic $\mathrm{Ca}^{2+}$ channels within the presynaptic terminal in a subunit-specific manner and may be involved in the organization of the $\mathrm{Ca}^{2+}$ channel relative to the release machinery [134].

The mutation of $\mathrm{Ca}_{\mathrm{V}} 2.1$ channels at the IQ-like motif in hippocampal neurons confirmed the mechanism of short-term synaptic facilitation dependent $\mathrm{nCaS}$ regulation of $\mathrm{Ca}_{\mathrm{V}} 2.1$ channels with brief and local $\mathrm{Ca}^{2+}$ elevation [135]. In addition, long-term potentiation of synaptic transmission at the Schaffer collateral-CA1 synapse, that is thought to be primarily generated postsynaptically, is substantially weakened by the mutation. Furthermore, the impairments in short-term and long-term plasticity due to $\mathrm{Ca}_{\mathrm{V}} 2.1$ channel mutation at the IQ-like motif are associated with pronounced deficits in spatial learning and memory in context-dependent fear conditioning and in the Barnes circular maze. Thus, regulation of $\mathrm{Cav}_{\mathrm{V}} 2.1$ channels by $\mathrm{CaM}$ and $\mathrm{nCaS}$ is required for not only presynaptic facilitation but also induction of postsynaptic long-term potentiation, and spatial learning and memory [136]. 


\subsection{Presynaptic Short-Term Depression}

At the calyx of Held, presynaptic stimulation at $100 \mathrm{~Hz}$ induces robust synaptic depression [88]. Synaptic depression during high-frequency APs bursts in presynaptic neurons is generally thought to be a result of SVs depletion [130]. In a prominent feature of synaptic transmission, the depression is caused by a decrease in release probability [103]. The release probability is determined by docked SVs and $\mathrm{Ca}^{2+}$ current in the AZ. Presynaptic loading of peptides that disrupt CaM interactions reduced both $\mathrm{Ca}^{2+}$-dependent inactivation of the P/Q-type $\mathrm{Ca}^{2+}$ current and PPD [88]. The $\mathrm{Ca}^{2+}$-dependent inactivation of the presynaptic $\mathrm{Ca}^{2+}$ current, rather than $\mathrm{SV}$ s depletion, causes rapid synaptic depression for stimuli ranging from 2 to $30 \mathrm{~Hz}[87,88]$.

The transfection of SCG neurons with $\mathrm{Ca}_{\mathrm{V}} 2.1$ channels lacking the CBD, a mutation reducing $\mathrm{Ca}^{2+}$-dependent inactivation in heterologous expression systems [80,81], blocked PPD, and reduced synaptic depression during APs burst up to $40 \mathrm{~Hz}$ [90]. CaBP1 expression, which blocks $\mathrm{Ca}^{2+}$-dependent facilitation of $\mathrm{P} / \mathrm{Q}$-type $\mathrm{Ca}^{2+}$ current, induced PPD, and synaptic depression during APs burst. However, the synaptic depression was absent in the presynaptic neuron coexpressed with CaBP1 and Cav2.1 channels lacking the CBD [113]. These results further demonstrate that rapid synaptic depression is caused by inactivation of presynaptic Cav2.1 channel bound with CaM or CaBP1. During APs burst at $30 \mathrm{~Hz}$ and $40 \mathrm{~Hz}$, a slower phase of synaptic depression is likely caused by SVs depletion.

Data from the calyx of Held and $\mathrm{Ca}_{\mathrm{V}} 2.1$-transfected SCG neurons suggest a conserved mechanism for generating rapid synaptic depression evoked by physiological rate and duration (at $40 \mathrm{~Hz}$ for $1 \mathrm{~s}$ ) of APs bursts in multiple synapses where neuronal activity elevates presynaptic $\mathrm{Ca}^{2+}$ transient, and such a $\mathrm{Ca}^{2+}$ rise dependent binding of $\mathrm{nCaS}$ to $\mathrm{Ca}_{\mathrm{V}} 2$ channels inactivates presynaptic $\mathrm{Ca}^{2+}$ channels. Studies of $\beta$ subunits within cultured hippocampal neurons also support an important role for $\mathrm{Ca}_{\mathrm{V}} 2$ channels modulation in synaptic plasticity: the overexpression of $\mathrm{Ca}_{\mathrm{V}} \beta 4$ favors facilitation whereas the overexpression of $\mathrm{Ca}_{\mathrm{V}} \beta 2$ favors depression [134].

\subsection{CaMKII Regulates Short-Term Synaptic Plasticity}

The binding of CaMKII to $\mathrm{Ca}_{\mathrm{V}} 2.1$ channels enhances their functional activity by inhibiting their inactivation [126] and enhances the activity of CaMKII by increasing its autophosphorylation [127]. SCG neurons introduced a competing peptide that blocks the interaction of CaMKII with Cav2.1 channels or SCG neurons transfected the brain-specific CaMKII inhibitor CaMKIIN [128] which prevents CaMKII binding to CaV2.1 channels [126] prevented not only PPF and PPD but also synaptic depression during APs burst and augmentation after a conditioning APs burst. It is unlikely that the basal release probability is affected by competing for peptide injection or CaMKIIN expression because the mean amplitudes of the first EPSPs are unchanged. Binding of CaMKII to the Cav2.1 channel is required for both up-regulation of channel activity in presynaptic facilitation and for $\mathrm{Ca}^{2+}$-independent activation of CaMKII by $\mathrm{Ca}_{\mathrm{V}} 2.1$, and one or both of these effects is necessary for normal short-term synaptic plasticity.

\section{4. $\mathrm{Ca}^{2+}$-Binding Molecules Regulate Short-Term Synaptic Plasticity}

Synaptotagmin-1, 2, and 9 serve as $\mathrm{Ca}^{2+}$ sensors to mediate the fast synchronous transmitter release as discussed above $[56,73,74]$. In contrast, synaptotagmin- 7 that binds slowly to $\mathrm{Ca}^{2+}$ via its $\mathrm{C}_{2} \mathrm{~A}$ domain [137] is not required for the synchronous synaptic transmission but mediates asynchronous transmitter release [111]. Synaptotagmin-7 is also required for the short-term facilitation, such as PPF and synaptic facilitation during APs burst, at several synapses [138]. Synaptotagmin-7 has a stronger contribution to membrane binding, and perhaps to bridging the vesicle and plasma membranes [111] that may enhance the fast transmitter release in response to repetitive APs firing.

In the presynaptic terminal $\mathrm{Ca}^{2+}$ buffers such as parvalbumin, calbindin, and related $\mathrm{Ca}^{2+}$-binding proteins control $\mathrm{Ca}^{2+}$ homeostasis [139] and synaptic strength [140-142]. A slow $\mathrm{Ca}^{2+}$ buffer 
parvalbumin [143] controls decay rate of short-term plasticity [144]. In contrast, a rapid $\mathrm{Ca}^{2+}$ buffer calbindin [145] alters short-term synaptic facilitation in multiple ways at different synapses [146].

Short-term plasticity may be a combination of the three molecular mechanisms, $\mathrm{Ca}^{2+}$ channel modulation, synaptotagmin-7 action and $\mathrm{Ca}^{2+}$ buffering, activated by $\mathrm{Ca}^{2+}$ elevation with neuronal firing. $\mathrm{Ca}^{2+}$ channel modulation with $\mathrm{CaM}$ and $\mathrm{nCaS}$ is a response to millisecond $\mathrm{Ca}^{2+}$ dynamics. The slower synaptotagmin-7 action integrates local and global $\mathrm{Ca}^{2+}$ entry, and $\mathrm{Ca}^{2+}$ buffering may control the spread $\mathrm{Ca}^{2+}$ accumulation [146].

\section{Conclusions}

In response to presynaptic AP firing, $\mathrm{Ca}^{2+}$ binding proteins triggers $\mathrm{SV}$ s exocytosis and regulate the probability. Thus, modulation of presynaptic $\mathrm{Ca}^{2+}$ channels has a powerful influence on synaptic transmission. At the pre-firing state, $\mathrm{Ca}^{2+}$ channels activity is inhibited by interaction with $\mathrm{AZ}$ proteins. AP firing relieves the inhibition by switching to interact with SNAREs and synaptotagmin, the effectors for $\mathrm{Ca}^{2+}$-dependent exocytosis. During and post firing, the activity of the $\mathrm{Cav}_{\mathrm{v}} 2.1$ channel is regulated by interaction with $\mathrm{CaM}$ and $\mathrm{nCaS}$ dependent on individual speed and affinity of binding to residual $\mathrm{Ca}^{2+}$. Interacting with CaMKII, the $\mathrm{Ca}_{\mathrm{V}} 2.1$ channel increases the binding to $\mathrm{CaM}$ and $\mathrm{nCaS}$ and their interaction causes short-term facilitation and depression of synaptic transmission. Fine-tuning the function and regulatory properties of presynaptic $\mathrm{P} / \mathrm{Q}$-type $\mathrm{Ca}^{2+}$ currents allow a greater range of input-output relationships and short-term plasticity. In contrast, tonic inhibition of $\mathrm{N}$-type $\mathrm{Ca}^{2+}$ currents is activated by G-protein coupled-autoreceptors and retrograde signaling receptors.

Acknowledgments: The author expresses her sincere thanks to all the collaborators concerned with the studies described in this review.

Conflicts of Interest: The authors declare no conflict of interest.

$\begin{array}{ll}\text { Abbreviations } \\ \text { APs } & \text { action potentials } \\ \text { AZ } & \text { active zone } \\ \text { CaV2 channels } & \text { voltage-gated } \mathrm{Ca}^{2+} \text { channels } \\ \text { SVs } & \text { synaptic vesicles } \\ \text { SCG } & \text { superior cervical ganglion } \\ \text { EPSPs } & \text { excitatory postsynaptic potentials } \\ \text { RIM } & \text { Rab-interacting molecule } \\ \text { RIM-BPs } & \text { RIM-binding proteins } \\ \text { nCaS } & \text { neuron specific Ca }{ }^{2+} \text { sensor proteins } \\ \text { CaM } & \text { calmodulin } \\ \text { CaBP1 } & \text { Ca }{ }^{2+} \text {-binding protein-1 } \\ \text { VILIP-2 } & \text { Visinin-like protein-2 } \\ \text { NCS-1 } & \text { neuronal calcium sensor-1 } \\ \text { CaMKII } & \text { Ca }{ }^{2+} / \text { CaM-dependent protein kinase II } \\ \text { PPF } & \text { paired-pulse facilitation } \\ \text { PPD } & \text { paired-pulse depression } \\ \text { ISI } & \text { inter-stimulus interval } \\ \text { PTP } & \text { post-tetanic potentiation }\end{array}$

\section{References}

1. Dunlap, K.; Luebke, J.I.; Turner, T.J. Exocytotic $\mathrm{Ca}^{2+}$ channels in mammalian central neurons. Trends Neurosci. 1995, 18, 89-98. [CrossRef]

2. Snutch, T.P.; Reiner, P.B. $\mathrm{Ca}^{2+}$ channels: Diversity of form and function. Curr. Opin. Neurobiol. 1992, 2, 247-253. [CrossRef]

3. Tedford, H.W.; Zamponi, G.W. Direct G protein modulation of Cav2 calcium channels. Pharm. Rev. 2006, 58, 837-862. [CrossRef] [PubMed] 
4. Catterall, W.A.; Few, A.P. Calcium channel regulation and presynaptic plasticity. Neuron 2008, 59, 882-901. [CrossRef]

5. Tsien, R.W.; Lipscombe, D.; Madison, D.V.; Bley, K.R.; Fox, A.P. Multiple types of neuronal calcium channels and their selective modulation. Trends Neurosci. 1988, 11, 431-438. [CrossRef]

6. Tsien, R.W.; Ellinor, P.T.; Horne, W.A. Molecular diversity of voltage-dependent $\mathrm{Ca}^{2+}$ channels. Trends Pharm. Sci. 1991, 12, 349-354. [CrossRef]

7. Miljanich, G.P.; Ramachandran, J. Antagonists of neuronal calcium channels: Structure, function, and therapeutic implications. Annu. Rev. Pharm. Toxicol. 1995, 35, 707-734. [CrossRef] [PubMed]

8. Catterall, W.A. Structure and regulation of voltage-gated $\mathrm{Ca}^{2+}$ channels. Annu. Rev. Cell Dev. Biol. 2000, 16, 521-555. [CrossRef]

9. Olivera, B.M.; Miljanich, G.P.; Ramachandran, J.; Adams, M. Calcium channel diversity and neurotransmitter release: The $\omega$-conotoxins and $\omega$-agatoxins. Annu. Rev. Biochem. 1994, 63, 823-867. [CrossRef]

10. Takahashi, M.; Seagar, M.J.; Jones, J.F.; Reber, B.F.; Catterall, W.A. Subunit structure of dihydropyridinesensitive calcium channels from skeletal muscle. Proc. Natl. Acad. Sci. USA 1987, 84, 5478-5482. [CrossRef]

11. Frank, H.Y.; Yarov-Yarovoy, V.; Gutman, G.A.; Catterall, W.A. Overview of molecular relationships in the voltage-gated ion channel superfamily. Pharmacol. Rev. 2005, 57, 387-395.

12. Wu, J.; Yan, Z.; Li, Z.; Yan, C.; Lu, S.; Dong, M.; Yan, N. Structure of the voltage-gated calcium channel Cav1.1 complex. Science 2015, 350, aad2395. [CrossRef] [PubMed]

13. Ertel, E.A.; Campbell, K.P.; Harpold, M.M.; Hofmann, F.; Mori, Y.; Perez-Reyes, E.; Schwartz, A.; Snutch, T.P.; Tanabe, T.; Birnbaumer, L.; et al. Nomenclature of voltage-gated calcium channels. Neuron 2000, 25, 533-535. [CrossRef]

14. Müller, C.S.; Haupt, A.; Bildl, W.; Schindler, J.; Knaus, H.G.; Meissner, M.; Meissner, B.; Striessnig, J.; Flockerzi, V.; Fakler, B.; et al. Quantitative proteomics of the Cav2 channel nano-environments in the mammalian brain. Proc. Natl. Acad. Sci. USA 2010, 107, 14950-14957. [CrossRef] [PubMed]

15. Dolphin, A.C. Beta subunits of voltage-gated calcium channels. J. Bioenerg. Biomembr. 2003, 35, 599-620. [CrossRef]

16. Hofmann, F.; Lacinova, L.; Klugbauer, N. Voltage-dependent calcium channels: From structure to function. Rev. Physiol. Biochem. Pharm. 1999, 139, 33-87.

17. Davies, A.; Hendrich, J.; Van Minh, A.T.; Wratten, J.; Douglas, L.; Dolphin, A.C. Functional biology of the $\alpha 2 \delta$ subunits of voltage-gated calcium channels. Trends Pharm. Sci. 2007, 28, 220-228. [CrossRef]

18. Hoppa, M.B.; Lana, B.; Margas, W.; Dolphin, A.C.; Ryan, T.A. $\alpha 2 \delta$ a expression sets presynaptic calcium channel abundance and release probability. Nature 2012, 486, 122-125. [CrossRef]

19. Hille, B. Modulation of ion-channel function by G-protein-coupled receptors. Trends Neurosci. 1994, 17, 531-536. [CrossRef]

20. Ikeda, S.R.; Dunlap, K. Voltage-dependent modulation of N-type calcium channels: Role of G protein subunits. Adv. Second Messenger Phosphoprot. Res. 1999, 33, 131-151.

21. Hertlitze, S.; Garcia, D.E.; Mackie, K.; Hille, B.; Scheuer, T.; Catterall, W.A. Modulation of Ca ${ }^{2+}$ channels by G-protein $\beta \gamma$ subunits. Nature 1996, 380, 258-262. [CrossRef]

22. Ikeda, S.R. Voltage-dependent modulation of N-type calcium channels by G-protein $\beta \gamma$ subunits. Nature 1996, 380, 255-258. [CrossRef] [PubMed]

23. Cantı, C.; Page, K.M.; Stephens, G.J.; Dolphin, A.C. Identification of residues in the N terminus of $\alpha 1 \mathrm{~B}$ critical for inhibition of the voltage-dependent calcium channel by G $\beta \gamma$. J. Neurosci. 1999, 19, 6855-6864. [CrossRef]

24. Zamponi, G.W.; Bourinet, E.; Nelson, D.; Nargeot, J.; Snutch, T.P. Crosstalk between G proteins and protein kinase $C$ mediated by the calcium channel $\alpha 1$ subunit. Nature 1997, 385, 442-446. [CrossRef]

25. Li, B.; Zhong, H.; Scheuer, T.; Catterall, W.A. Functional role of a C-terminal G $\beta \gamma$-binding domain of Cav2.2 channels. Mol. Pharm. 2004, 66, 761-769.

26. Bean, B.P. Neurotransmitter inhibition of neuronal calcium currents by changes in channel voltage dependence. Nature 1989, 340, 153-156. [CrossRef] [PubMed]

27. Marchetti, C.; Carbone, E.; Lux, H.D. Effects of dopamine and noradrenaline on Ca channels of cultured sensory and sympathetic neurons of chick. Pflug. Arch. 1986, 406, 104-111. [CrossRef]

28. Tsunoo, A.; Yoshii, M.; Narahashi, T. Block of calcium channels by enkephalin and somatostatin in neuroblastoma-glioma hybrid NG108-15 cells. Proc. Natl. Acad. Sci. USA 1986, 83, 9832-9836. [CrossRef] 
29. Canti, C.; Bogdanov, Y.; Dolphin, A.C. Interaction between G proteins and accessory subunits in the regulation of $1 \mathrm{~B}$ calcium channels in Xenopus oocytes. J. Physiol. 2000, 527 Pt. 3, 419-432. [CrossRef]

30. Feng, Z.P.; Arnot, M.I.; Doering, C.J.; Zamponi, G.W. Calcium channel beta subunits differentially regulate the inhibition of N-type channels by individual G $\beta$ isoforms. J. Biol. Chem. 2001, 276, 45051-45058. [CrossRef]

31. Dresviannikov, A.V.; Page, K.M.; Leroy, J.; Pratt, W.S.; Dolphin, A.C. Determinants of the voltage dependence of $\mathrm{G}$ protein modulation within calcium channel beta subunits. Pflug. Arch. 2009, 457, 743-756. [CrossRef]

32. Zamponi, G.W.; Currie, K.P. Regulation of $\mathrm{Ca}_{\mathrm{V}} 2$ calcium channels by $\mathrm{G}$ protein coupled receptors. Biochim. Biophys. Acta 2013, 1828, 1629-1643. [CrossRef]

33. García, D.E.; Li, B.; García-Ferreiro, R.E.; Hernández-Ochoa, E.O.; Yan, K.; Gautam, N.; Catterall, W.A.; Mackie, K.; Hille, B. G-protein beta-subunit specificity in the fast membrane-delimited inhibition of $\mathrm{Ca}^{2+}$ channels. J. Neurosci. 1998, 18, 9163-9170. [CrossRef]

34. Reyes-Vaca, A.; de la Cruz, L.; Garduño, J.; Arenas, I.; Garcia, D.E. Fast Inactivation of Ca 2.2 Channels Is Prevented by the Gß1 Subunit in Rat Sympathetic Neurons. J. Mol. Neurosci 2017, 63, 377-384. [CrossRef]

35. Hernández-Castellanos, J.M.; Vivas, O.; Garduño, J.; De la Cruz, L.; Arenas, I.; Elías-Viñas, D.; Mackie, K.; García, D.E. G $\beta_{2}$ mimics activation kinetic slowing of $\mathrm{Ca}_{\mathrm{V}} 2.2$ channels by noradrenaline in rat sympathetic neurons. Biochem. Biophys. Res. Commun. 2014, 445, 250-254. [CrossRef]

36. Mahmoud, S.; Yun, J.K.; Ruiz-Velasco, V. Gß2 and G $\beta 4$ participate in the opioid and adrenergic receptor-mediated $\mathrm{Ca}^{2+}$ channel modulation in rat sympathetic neurons. J. Physiol. 2012, 590, 4673-4689. [CrossRef]

37. Arnot, M.I.; Stotz, S.C.; Jarvis, S.E.; Zamponi, G.W. Differential modulation of N-type 1B and P/Q-type 1A calcium channels by different G protein subunit isoforms. J. Physiol. 2000, 527 Pt. 2, 203-212. [CrossRef]

38. Stanley, E.F.; Mirotznik, R.R. Cleavage of syntaxin prevents G-protein regulation of presynaptic calcium channels. Nature 1997, 385, 340-343. [CrossRef]

39. Jarvis, S.E.; Magga, J.M.; Beedle, A.M.; Braun, J.E.; Zamponi, G.W. G protein modulation of N-type calcium channels is facilitated by physical interactions between syntaxin 1A and G $\beta \gamma$. J. Biol. Chem. 2000, 275, 6388-6394. [CrossRef]

40. Strock, J.; Diverse-Pierluissi, M.A. $\mathrm{Ca}^{2+}$ channels as integrators of G protein-mediated signaling in neurons. Mol. Pharm. 2004, 66, 1071-1076. [CrossRef]

41. Delmas, P.; Coste, B.; Gamper, N.; Shapiro, M.S. Phosphoinositide lipid second messengers: New paradigms for calcium channel modulation. Neuron 2005, 47, 179-182. [CrossRef]

42. Kubista, H.; Kosenburger, K.; Mahlknecht, P.; Drobny, H.; Boehm, S. Inhibition of transmitter release from rat sympathetic neurons via presynaptic $\mathrm{M}_{1}$ muscarinic acetylcholine receptors. Br. J. Pharm 2009, 156, 1342-1352. [CrossRef]

43. Koushika, S.P.; Richmond, J.E.; Hadwiger, G.; Weimer, R.M.; Jorgensen, E.M.; Nonet, M.L. A post-docking role for active zone protein Rim. Nat. Neurosci. 2001, 4, 997-1005. [CrossRef]

44. Schoch, S.; Mittelstaedt, T.; Kaeser, P.S.; Padgett, D.; Feldmann, N.; Chevaleyre, V.; Castillo, P.E.; Hammer, R.E.; Han, W.; Schmitz, F.; et al. Redundant functions of RIM1 $\alpha$ and RIM2 $\alpha$ in $\mathrm{Ca}^{2+}$-triggered neurotransmitter release. EMBO J. 2006, 25, 5852-5863. [CrossRef]

45. Gracheva, E.O.; Hadwiger, G.; Nonet, M.L.; Richmond, J.E. Direct interactions between C. elegans RAB-3 and Rim provide a mechanism to target vesicles to the presynaptic density. Neurosci. Lett. 2008, 444, 137-142. [CrossRef]

46. Kaeser, P.S.; Deng, L.; Wang, Y.; Dulubova, I.; Liu, X.; Rizo, J.; Südhof, T.C. RIM proteins tether Ca ${ }^{2+}$ channels to presynaptic active zones via a direct PDZ-domain interaction. Cell 2011, 144, 282-295. [CrossRef]

47. Deng, L.; Kaeser, P.S.; Xu, W.; Südhof, T.C. RIM proteins activate vesicle priming by reversing autoinhibitory homodimerization of Munc13. Neuron 2011, 69, 317-331. [CrossRef]

48. Han, Y.; Kaeser, P.S.; Südhof, T.C.; Schneggenburger, R. RIM determines $\mathrm{Ca}^{2+}$ channel density and vesicle docking at the presynaptic active zone. Neuron 2011, 69, 304-316. [CrossRef]

49. Castillo, P.E.; Schoch, S.; Schmitz, F.; Südhof, T.C.; Malenka, R.C. RIM1 $\alpha$ is required for presynaptic long-term potentiation. Nature 2002, 415, 327-330. [CrossRef]

50. Coppola, T.; Magnin-Lüthi, S.; Perret-Menoud, V.; Gattesco, S.; Schiavo, G.; Regazzi, R. Direct interaction of the Rab3 effector RIM with $\mathrm{Ca}^{2+}$ channels, SNAP-25, and synaptotagmin. J. Biol. Chem. 2001, 276, 32756-32762. [CrossRef] 
51. Hibino, H.; Pironkova, R.; Onwumere, O.; Vologodskaia, M.; Hudspeth, A.J.; Lesage, F. RIM binding proteins (RBPs) couple Rab3-interacting molecules (RIMs) to voltage-gated $\mathrm{Ca}^{2+}$ channels. Neuron 2002, 34, 411-423. [CrossRef]

52. Acuna, C.; Liu, X.; Gonzalez, A.; Südhof, T.C. RIM-BPs Mediate tight coupling of action potentials to $\mathrm{Ca}^{2+}$-triggered neurotransmitter release. Neuron 2015, 87, 1234-1247. [CrossRef]

53. Kiyonaka, S.; Wakamori, M.; Miki, T.; Uriu, Y.; Nonaka, M.; Bito, H.; Beedle, A.M.; Mori, E.; Hara, Y.; De Waard, M.; et al. RIM1 confers sustained activity and neurotransmitter vesicle anchoring to presynaptic $\mathrm{Ca}^{2+}$ channels. Nat. Neurosci 2007, 10, 691-701. [CrossRef]

54. Kiyonaka, S.; Nakajima, H.; Takada, Y.; Hida, Y.; Yoshioka, T.; Hagiwara, A.; Kitajima, I.; Mori, Y.; Ohtsuka, T. Physical and functional interaction of the active zone protein CAST/ERC2 and the $\beta$-subunit of the voltage-dependent $\mathrm{Ca}^{2+}$ channel. J. Biochem. 2012, 152, 149-159. [CrossRef]

55. Calloway, N.; Gouzer, G.; Xue, M.; Ryan, T.A. The active-zone protein Munc13 controls the use-dependence of presynaptic voltage-gated calcium channels. Elife 2015, 4, 1-15. [CrossRef]

56. Sudhof, T.C. The synaptic vesicle cycle. Annu. Rev. Neurosci 2004, 27, 509-547. [CrossRef]

57. Cohen, M.W.; Jones, O.T.; Angelides, K.J. Distribution of $\mathrm{Ca}^{2+}$ channels on frog motor nerve terminals revealed by fluorescent omega-conotoxin. J. Neurosci. 1991, 11, 1032-1039. [CrossRef]

58. Westenbroek, R.E.; Hell, J.W.; Warner, C.; Dubel, S.J.; Snutch, T.P.; Catterall, W.A. Biochemical properties and subcellular distribution of an N-type calcium channel $\alpha 1$ subunit. Neuron 1992, 9, 1099-1115. [CrossRef]

59. Westenbroek, R.E.; Sakurai, T.; Elliott, E.M.; Hell, J.W.; Starr, T.V.; Snutch, T.P.; Catterall, W.A. Immunochemical identification and subcellular distribution of the $\alpha 1 \mathrm{~A}$ subunits of brain calcium channels. J. Neurosci. 1995, 15, 6403-6418. [CrossRef]

60. Bennett, M.K.; Calakos, N.; Scheller, R.H. Syntaxin: A synaptic protein implicated in docking of synaptic vesicles at presynaptic active zones. Science 1992, 257, 255-259. [CrossRef]

61. Leveque, C.; el Far, O.U.S.S.A.M.A.; Martin-Moutot, N.; Sato, K.; Kato, R.; Takahashi, M.; Seagar, M.J. Purification of the N-type calcium channel associated with syntaxin and synaptotagmin. A complex implicated in synaptic vesicle exocytosis. J. Biol. Chem. 1994, 269, 6306-6312.

62. Yoshida, A.; Oho, C.; Omori, A.; Kuwahara, R.; Ito, T.; Takahashi, M. HPC-1 is associated with synaptotagmin and $\omega$-conotoxin receptor. J. Biol. Chem. 1992, 267, 24925-24928.

63. Sheng, Z.H.; Rettig, J.; Cook, T.; Catterall, W.A. Calcium-dependent interaction of N-type calcium channels with the synaptic core complex. Nature 1996, 379, 451-454. [CrossRef]

64. Sheng, Z.H.; Rettig, J.; Takahashi, M.; Catterall, W.A. Identification of a syntaxin-binding site on N-type calcium channels. Neuron 1994, 13, 1303-1313. [CrossRef]

65. Yokoyama, C.T.; Myers, S.J.; Fu, J.; Mockus, S.M.; Scheuer, T.; Catterall, W.A. Mechanism of SNARE protein binding and regulation of Cav2 channels by phosphorylation of the synaptic protein interaction site. Mol. Cell Neurosci. 2005, 28, 1-17. [CrossRef]

66. Kim, D.K.; Catterall, W.A. $\mathrm{Ca}^{2+}$-dependent and -independent interactions of the isoforms of the alpha1A subunit of brain $\mathrm{Ca}^{2+}$ channels with presynaptic SNARE proteins. Proc. Natl. Acad. Sci. USA 1997, 94, 14782-14786. [CrossRef]

67. Rettig, J.; Sheng, Z.H.; Kim, D.K.; Hodson, C.D.; Snutch, T.P.; Catterall, W.A. Isoform-specific interaction of the alpha1A subunits of brain $\mathrm{Ca}^{2+}$ channels with the presynaptic proteins syntaxin and SNAP-25. Proc. Natl. Acad. Sci. USA 1996, 93, 7363-7368. [CrossRef]

68. Bezprozvanny, I.; Scheller, R.H.; Tsien, R.W. Functional impact of syntaxin on gating of N-type and Q-type calcium channels. Nature 1995, 378, 623-626. [CrossRef]

69. Wiser, O.; Bennett, M.K.; Atlas, D. Functional interaction of syntaxin and SNAP-25 with voltage-sensitive Land N-type $\mathrm{Ca}^{2+}$ channels. Embo J. 1996, 15, 4100-4110. [CrossRef]

70. Zhong, H.; Yokoyama, C.T.; Scheuer, T.; Catterall, W.A. Reciprocal regulation of P/Q-type Ca ${ }^{2+}$ channels by SNAP-25, syntaxin and synaptotagmin. Nat. Neurosci. 1999, 2, 939-941. [CrossRef]

71. Jarvis, S.E.; Zamponi, G.W. Distinct molecular determinants govern syntaxin 1A-mediated inactivation and G-protein inhibition of N-type calcium channels. J. Neurosci. 2001, 21, 2939-2948. [CrossRef]

72. Bezprozvanny, I.; Zhong, P.; Scheller, R.H.; Tsien, R.W. Molecular determinants of the functional interaction between syntaxin and $\mathrm{N}$-type $\mathrm{Ca}^{2+}$ channel gating. Proc. Natl. Acad. Sci. USA 2000, 97, 13943-13948. [CrossRef] 
73. Geppert, M.; Goda, Y.; Hammer, R.E.; Li, C.; Rosahl, T.W.; Stevens, C.F.; Südhof, T.C. Synaptotagmin I: A major $\mathrm{Ca}^{2+}$ sensor for transmitter release at a central synapse. Cell 1994, 79, 717-727. [CrossRef]

74. Xu, J.; Mashimo, T.; Sudhof, T.C. Synaptotagmin-1, -2, and -9: $\mathrm{Ca}^{2+}$ sensors for fast release that specify distinct presynaptic properties in subsets of neurons. Neuron 2007, 54,567-581. [CrossRef]

75. Sheng, Z.H.; Yokoyama, C.T.; Catterall, W.A. Interaction of the synprint site of N-type $\mathrm{Ca}^{2+}$ channels with the C2B domain of synaptotagmin I. Proc. Natl. Acad. Sci. USA 1997, 94, 5405-5410. [CrossRef]

76. Wiser, O.; Tobi, D.; Trus, M.; Atlas, D. Synaptotagmin restores kinetic properties of a syntaxin-associated N-type voltage sensitive calcium channel. FEBS Lett. 1997, 404, 203-207. [CrossRef]

77. Yokoyama, C.T.; Sheng, Z.H.; Catterall, W.A. Phosphorylation of the synaptic protein interaction site on N-type calcium channels inhibits interactions with SNARE proteins. J. Neurosci. 1997, 17, 6929-6938. [CrossRef]

78. DeMaria, C.D.; Soong, T.W.; Alseikhan, B.A.; Alvania, R.S.; Yue, D.T. Calmodulin bifurcates the local Ca ${ }^{2+}$ signal that modulates $\mathrm{P} / \mathrm{Q}-t y p e \mathrm{Ca}^{2+}$ channels. Nature 2001, 411, 484-489. [CrossRef]

79. Lee, A.; Scheuer, T.; Catterall, W.A. $\mathrm{Ca}^{2+} /$ calmodulin-dependent facilitation and inactivation of P/Q-type $\mathrm{Ca}^{2+}$ channels. J. Neurosci. 2000, 20,6830-6838. [CrossRef]

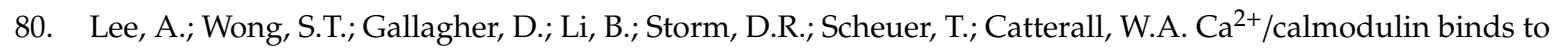
and modulates P/Q-type calcium channels. Nature 1999, 399, 155-159. [CrossRef]

81. Lee, A.; Zhou, H.; Scheuer, T.; Catterall, W.A. Molecular determinants of $\mathrm{Ca}^{2+} /$ calmodulin-dependent regulation of $\mathrm{Ca}_{\mathrm{V}} 2.1$ channels. Proc. Natl. Acad. Sci. USA 2003, 100, 16059-16064. [CrossRef]

82. Few, A.P.; Lautermilch, N.J.; Westenbroek, R.E.; Scheuer, T.; Catterall, W.A. Differential regulation of $\mathrm{Ca}_{\mathrm{V}} 2.1$ channels by calcium-binding protein 1 and visinin-like protein-2 requires $\mathrm{N}$-terminal myristoylation. J. Neurosci. 2005, 25, 7071-7080. [CrossRef]

83. Lautermilch, N.J.; Few, A.P.; Scheuer, T.; Catterall, W.A. Modulation of $\mathrm{Ca}_{\mathrm{V}} 2.1$ channels by the neuronal calcium-binding protein visinin-like protein-2. J. Neurosci. 2005, 25, 7062-7070. [CrossRef]

84. Lee, A.; Westenbroek, R.E.; Haeseleer, F.; Palczewski, K.; Scheuer, T.; Catterall, W.A. Differential modulation of $\mathrm{Ca}_{\mathrm{V}} 2.1$ channels by calmodulin and $\mathrm{Ca}^{2+}$-binding protein 1. Nat. Neurosci. 2002, 5, 210-217. [CrossRef]

85. Yan, J.; Leal, K.; Magupalli, V.G.; Nanou, E.; Martinez, G.Q.; Scheuer, T.; Catterall, W.A. Modulation of Cav2.1 channels by neuronal calcium sensor-1 induces short-term synaptic facilitation. Mol. Cell Neurosci. 2014, 63, 124-131. [CrossRef]

86. Liu, H.; De Waard, M.; Scott, V.E.; Gurnett, C.A.; Lennon, V.A.; Campbell, K.P. Identification of three subunits of the high affinity omega-conotoxin MVIIC-sensitive $\mathrm{Ca}^{2+}$ channel. J. Biol. Chem. 1996, 271, 13804-13810. [CrossRef]

87. Forsythe, I.D.; Tsujimoto, T.; Barnes-Davies, M.; Cuttle, M.F.; Takahashi, T. Inactivation of presynaptic calcium current contributes to synaptic depression at a fast central synapse. Neuron 1998, 20, 797-807. [CrossRef]

88. $\mathrm{Xu}, \mathrm{J} . ; \mathrm{Wu}, \mathrm{L} . \mathrm{G}$. The decrease in the presynaptic calcium current is a major cause of short-term depression at a calyx-type synapse. Neuron 2005, 46, 633-645. [CrossRef]

89. Chaudhuri, D.; Alseikhan, B.A.; Chang, S.Y.; Soong, T.W.; Yue, D.T. Developmental activation of calmodulin-dependent facilitation of cerebellar P-type $\mathrm{Ca}^{2+}$ current. J. Neurosci. 2005, 25, 8282-8294. [CrossRef]

90. Mochida, S.; Few, A.P.; Scheuer, T.; Catterall, W.A. Regulation of presynaptic Ca 2.1 channels by Ca ${ }^{2+}$ sensor proteins mediates short-term synaptic plasticity. Neuron 2008, 57, 210-216.

91. Kajikawa, Y.; Saitoh, N.; Takahashi, T. GTP-binding protein $\beta \gamma$ subunits mediate presynaptic calcium current

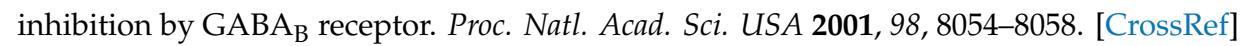

92. Takahashi, T.; Forsythe, I.D.; Tsujimoto, T.; Barnes-Davies, M.; Onodera, K. Presynaptic calcium current modulation by a metabotropic glutamate receptor. Science 1996, 274, 594-597. [CrossRef]

93. Brown, S.P.; Safo, P.K.; Regehr, W.G. Endocannabinoids inhibit transmission at granule cell to Purkinje cell synapses by modulating three types of presynaptic calcium channels. J. Neurosci. 2004, 24, 5623-5631. [CrossRef]

94. Brody, D.L.; Yue, D.T. Relief of G-protein inhibition of calcium channels and short-term synaptic facilitation in cultured hippocampal neurons. J. Neurosci. 2000, 20, 889-898. [CrossRef]

95. Han, J.; Mark, M.D.; Li, X.; Xie, M.; Waka, S.; Rettig, J.; Herlitze, S. RGS2 determines short-term synaptic plasticity in hippocampal neurons by regulating Gi/o-mediated inhibition of presynaptic $\mathrm{Ca}^{2+}$ channels. Neuron 2006, 51, 575-586. [CrossRef] 
96. Kreitzer, A.C.; Regehr, W.G. Modulation of transmission during trains at a cerebellar synapse. J. Neurosci. 2000, 20, 1348-1357. [CrossRef]

97. Stephens, G.J.; Mochida, S. G protein $\beta \gamma$ subunits mediate presynaptic inhibition of transmitter release from rat superior cervical ganglion neurones in culture. J. Physiol. 2005, 563, 765-776. [CrossRef]

98. Bucci, G.; Mochida, S.; Stephens, G.J. Inhibition of synaptic transmission and G protein modulation by synthetic Ca $2.2 \mathrm{Ca}^{2+}$ channel peptides. J. Physiol. 2011, 589, 3085-3101. [CrossRef]

99. Mochida, S.; Sheng, Z.H.; Baker, C.; Kobayashi, H.; Catterall, W.A. Inhibition of neurotransmission by peptides containing the synaptic protein interaction site of N-type $\mathrm{Ca}^{2+}$ channels. Neuron 1996, 17, 781-788. [CrossRef]

100. Rettig, J.; Heinemann, C.; Ashery, U.; Sheng, Z.H.; Yokoyama, C.T.; Catterall, W.A.; Neher, E. Alteration of $\mathrm{Ca}^{2+}$ dependence of neurotransmitter release by disruption of $\mathrm{Ca}^{2+}$ channel/syntaxin interaction. J. Neurosci. 1997, 17, 6647-6656. [CrossRef]

101. Inchauspe, C.G.; Forsythe, I.D.; Uchitel, O.D. Changes in synaptic transmission properties due to the expression of $\mathrm{N}$-type calcium channels at the calyx of Held synapse of mice lacking $\mathrm{P} / \mathrm{Q}$-type calcium channels. J. Physiol. 2007, 584, 835-851. [CrossRef]

102. Iwasaki, S.; Momiyama, A.; Uchitel, O.D.; Takahashi, T. Developmental changes in calcium channel types mediating central synaptic transmission. J. Neurosci. 2000, 20, 59-65. [CrossRef]

103. Wu, L.G.; Borst, J.G. The reduced release probability of releasable vesicles during recovery from short-term synaptic depression. Neuron 1999, 23, 821-832. [CrossRef]

104. Wadel, K.; Neher, E.; Sakaba, T. The coupling between synaptic vesicles and $\mathrm{Ca}^{2+}$ channels determines fast neurotransmitter release. Neuron 2007, 53, 563-575. [CrossRef]

105. Wu, L.G.; Westenbroek, R.E.; Borst, J.G.G.; Catterall, W.A.; Sakmann, B. Calcium channel types with distinct presynaptic localization couple differentially to transmitter release in single calyx-type synapses. J. Neurosci. 1999, 19, 726-736. [CrossRef]

106. Keith, R.K.; Poage, R.E.; Yokoyama, C.T.; Catterall, W.A.; Meriney, S.D. Bidirectional modulation of transmitter release by calcium channel/syntaxin interactions in vivo. J. Neurosci. 2007, 27, 265-269. [CrossRef]

107. Mochida, S.; Nonomura, Y.; Kobayashi, H. Analysis of the mechanism for acetylcholine release at the synapse formed between rat sympathetic neurons in culture. Microsc. Res. Tech. 1994, 29, 94-102. [CrossRef]

108. Ma, H.; Mochida, S. A cholinergic model synapse to elucidate protein function at presynaptic terminals. Neurosci. Res. 2007, 57, 491-498. [CrossRef]

109. Mochida, S.; Saisu, H.; Kobayashi, H.; Abe, T. Impairment of syntaxin by botulinum neurotoxin C1 or antibodies inhibits acetylcholine release but not $\mathrm{Ca}^{2+}$ channel activity. Neuroscience 1995, 65, 905-915. [CrossRef]

110. Mochida, S.; Westenbroek, R.E.; Yokoyama, C.T.; Itoh, K.; Catterall, W.A. Subtype-selective reconstitution of synaptic transmission in sympathetic ganglion neurons by expression of exogenous calcium channels. Proc. Natl. Acad. Sci. USA 2003, 100, 2813-2818. [CrossRef]

111. Voleti, R.; Tomchick, D.R.; Südhof, T.C.; Rizo, J. Exceptionally tight membrane-binding may explain the key role of the synaptotagmin-7 C2A domain in asynchronous neurotransmitter release. Proc. Natl. Acad. Sci. USA 2017, 114, E8518-E8527. [CrossRef]

112. Voleti, R.; Tomchick, D.R.; Südhof, T.C.; Rizo, J. Calmodulin as a direct detector of $\mathrm{Ca}^{2+}$ signals. Nat. Neurosci. 2011, 14, 301-304.

113. Leal, K.; Mochida, S.; Scheuer, T.; Catterall, W.A. Fine-tuning synaptic plasticity by modulation of Ca 2.1 channels with $\mathrm{Ca}^{2+}$ sensor proteins. Proc. Natl. Acad. Sci. USA 2012, 109, 17069-17074. [CrossRef]

114. Haeseleer, F.; Sokal, I.; Verlinde, C.L.; Erdjument-Bromage, H.; Tempst, P.; Pronin, A.N.; Benovic, J.L.; Fariss, R.N.; Palczewski, K. Five members of a novel $\mathrm{Ca}^{2+}$-binding protein (CABP) subfamily with similarity to calmodulin. J. Biol. Chem. 2000, 275, 1247-1260. [CrossRef]

115. Burgoyne, R.D.; Weiss, J.L. The neuronal calcium sensor family of $\mathrm{Ca}^{2+}$-binding proteins. Biochem. J. 2001, 353, 1-12. [CrossRef]

116. Mikhaylova, M.; Hradsky, J.; Kreutz, M.R. Between promiscuity and specificity: Novel roles of EF-hand calcium sensors in neuronal $\mathrm{Ca}^{2+}$ signaling. J. Neurochem. 2011, 118, 695-713. [CrossRef]

117. Abbott, L.F.; Regehr, W.G. Synaptic computation. Nature 2004, 431, 796-803. [CrossRef] 
118. Kennedy, M.B.; Bennett, M.K.; Bulleit, R.F.; Erondu, N.E.; Jennings, V.R.; Miller, S.G.; Molloy, S.S.; Patton, B.L.; Schenker, L.J. Structure and regulation of type II calcium/calmodulin-dependent protein kinase in central nervous system neurons. Cold Spring Harb. Symp. Quant. Biol. 1990, 55, 101-110. [CrossRef]

119. Lüscher, C.; Nicoll, R.A.; Malenka, R.C.; Muller, D. Synaptic plasticity and dynamic modulation of the postsynaptic membrane. Nat. Neurosci. 2000, 3, 545-550. [CrossRef]

120. Schulman, H.; Greengard, P. $\mathrm{Ca}^{2+}$-dependent protein phosphorylation system in membranes from various tissues, and its activation by "calcium-dependent regulator". Proc. Natl. Acad. Sci. USA 1978, 75, 5432-5436. [CrossRef]

121. Shepherd, J.D.; Huganir, R.L. The cell biology of synaptic plasticity: AMPA receptor trafficking. Annu. Rev. Cell Dev. Biol. 2007, 23, 613-643. [CrossRef]

122. Llinas, R.; McGuinness, T.L.; Leonard, C.S.; Sugimori, M.; Greengard, P. Intraterminal injection of synapsin I or calcium/calmodulin-dependent protein kinase II alters neurotransmitter release at the squid giant synapse. Proc. Natl. Acad. Sci. USA 1985, 82, 3035-3039. [CrossRef]

123. Llinas, R.; Gruner, J.A.; Sugimori, M.; McGuinness, T.L.; Greengard, P. Regulation by synapsin I and $\mathrm{Ca}^{2+}$-calmodulin-dependent protein kinase II of the transmitter release in squid giant synapse. J. Physiol. 1991, 436, 257-282. [CrossRef]

124. Chapman, P.F.; Frenguelli, B.G.; Smith, A.; Chen, C.M.; Silva, A.J. The $\alpha-\mathrm{Ca}^{2+} /$ calmodulin kinase II: A bidirectional modulator of presynaptic plasticity. Neuron 1995, 14, 591-597. [CrossRef]

125. Lu, F.M.; Hawkins, R.D. Presynaptic and postsynaptic $\mathrm{Ca}^{2+}$ and CamKII contribute to long-term potentiation at synapses between individual CA3 neurons. Proc. Natl. Acad. Sci. USA 2006, 103, 4264-4269. [CrossRef]

126. Jiang, X.; Lautermilch, N.J.; Watari, H.; Westenbroek, R.E.; Scheuer, T.; Catterall, W.A. Modulation of Cav2.1 channels by $\mathrm{Ca}^{2+} /$ calmodulin-dependent protein kinase II bound to the C-terminal domain. Proc. Natl. Acad. Sc. USA 2008, 105, 341-346. [CrossRef]

127. Magupalli, V.G.; Mochida, S.; Yan, J.; Jiang, X.; Westenbroek, R.E.; Nairn, A.C.; Scheuer, T.; Catterall, W.A. $\mathrm{Ca}^{2+}$-independent activation of $\mathrm{Ca}^{2+} /$ calmodulin-dependent protein kinase II bound to the C-terminal domain of Cav2.1 calcium channels. J. Biol. Chem. 2013, 288, 4637-4648. [CrossRef]

128. Chang, B.H.; Mukherji, S.; Soderling, T.R. Characterization of a calmodulin kinase II inhibitor protein in brain. Proc. Natl. Acad. Sci. USA 1998, 95, 10890-10895. [CrossRef]

129. Benfenati, F.; Valtorta, F.; Chieregatti, E.; Greengard, P. Interaction of free and synaptic vesicle-bound synapsin I with F-actin. Neuron 1992, 8, 377-386. [CrossRef]

130. Zucker, R.S.; Regehr, W.G. Short-term synaptic plasticity. Annu. Rev. Physiol. 2002, 64, 355-405. [CrossRef]

131. Inchauspe, C.G.; Martini, F.J.; Forsythe, I.D.; Uchitel, O.D. Functional compensation of P/Q by N-type channels blocks short-term plasticity at the calyx of Held presynaptic terminal. J. Neurosci. 2004, 24, 10379-10383. [CrossRef]

132. Ishikawa, T.; Kaneko, M.; Shin, H.S.; Takahashi, T. Presynaptic N-type and P/Q-type Ca ${ }^{2+}$ channels mediating synaptic transmission at the calyx of Held of mice. J. Physiol. 2005, 568, 199-209. [CrossRef]

133. Habets, R.L.; Borst, J.G. Post-tetanic potentiation in the rat calyx of Held synapse. J. Physiol 2005, 564, $173-187$. [CrossRef]

134. Xie, M.; Li, X.; Han, J.; Vogt, D.L.; Wittemann, S.; Mark, M.D.; Herlitze, S. Facilitation versus depression in cultured hippocampal neurons determined by targeting of $\mathrm{Ca}^{2+}$ channel Cavbeta4 versus $\mathrm{Cav} \beta 2$ subunits to synaptic terminals. J. Cell Biol. 2007, 178, 489-502. [CrossRef]

135. Nanou, E.; Sullivan, J.M.; Scheuer, T.; Catterall, W.A. Calcium sensor regulation of the $\mathrm{Ca}_{\mathrm{V}} 2.1 \mathrm{Ca}^{2+}$ channel contributes to short-term synaptic plasticity in hippocampal neurons. Proc. Natl. Acad. Sci. USA 2016, 113, 1062-1067. [CrossRef]

136. Nanou, E.; Scheuer, T.; Catterall, W.A. Calcium sensor regulation of the $\mathrm{Ca}_{\mathrm{V}} 2.1 \mathrm{Ca}^{2+}$ channel contributes to long-term potentiation and spatial learning. Proc. Natl. Acad. Sci. USA 2016, 113, 13209-13214. [CrossRef]

137. Maximov, A.; Lao, Y.; Li, H.; Chen, X.; Rizo, J.; Sørensen, J.B.; Südhof, T.C. Genetic analysis of synaptotagmin-7 function in synaptic vesicle exocytosis. Proc. Natl. Acad. Sci. USA 2008, 105, 3986-3991. [CrossRef]

138. Jackman, S.L.; Turecek, J.; Belinsky, J.E.; Regehr, W.G. The calcium sensor synaptotagmin 7 is required for synaptic facilitation. Nature 2016, 529, 88-91. [CrossRef]

139. Schwaller, B. Cytosolic $\mathrm{Ca}^{2+}$ buffers. Cold Spring Harb. Perspect. Biol. 2010, 2, a004051. [CrossRef]

140. Gainey, M.A.; Feldman, D.E. Multiple shared mechanisms for homeostatic plasticity in rodent somatosensory and visual cortex. Philos. Trans. R. Soc. Lond. B. Biol. Sci. 2017, 372, 1-7. [CrossRef] 
141. Chevaleyre, V.; Piskorowski, R. Modulating excitation through plasticity at inhibitory synapses. Front. Cell Neurosci. 2014, 8, 1-7. [CrossRef]

142. Cheron, G.; Servais, L.; Dan, B. Cerebellar network plasticity: From genes to fast oscillation. Neuroscience 2008, 153, 1-19. [CrossRef]

143. Lee, S.H.; Schwaller, B.; Neher, E. Kinetics of $\mathrm{Ca}^{2+}$ binding to parvalbumin in bovine chromaffin cells: Implications for $\mathrm{Ca}^{2+}$ transients of neuronal dendrites. J. Physiol. 2000, 525, 419-432. [CrossRef]

144. Müller, M.; Felmy, F.; Schwaller, B.; Schneggenburger, R. Parvalbumin is a mobile presynaptic $\mathrm{Ca}^{2+} \mathrm{buffer}$ in the calyx of Held that accelerates the decay of $\mathrm{Ca}^{2+}$ and short-term facilitation. J. Neurosci. 2007, 27, 2261-2271. [CrossRef]

145. Nägerl, U.V.; Novo, D.; Mody, I.; Vergara, J.L. Binding kinetics of calbindin-D(28k) determined by flash photolysis of caged $\mathrm{Ca}^{2+}$. Biophys. J. 2000, 79, 3009-3018. [CrossRef]

146. Nanou, E.; Catterall, W.A. Calcium Channels, Synaptic Plasticity, and Neuropsychiatric Disease. Neuron 2018, 98, 466-481. [CrossRef]

(C) 2019 by the author. Licensee MDPI, Basel, Switzerland. This article is an open access article distributed under the terms and conditions of the Creative Commons Attribution (CC BY) license (http://creativecommons.org/licenses/by/4.0/). 